\title{
The WHO Response to the Pandemic Coronavirus (Covid-19) Outbreak: An Evaluation Under the Rule of International Law
}

\author{
Salwa Youssef Elekyabi \\ Associate Professor- Faculty of Law - Zagazig University
}

\begin{abstract}
:
The outbreak of Coronavirus (Covid-19) pandemic has posed a serious threat to the international community and has impacted almost all sectors. Globally, pandemic outbreaks couldn't be fought or eradicated by one state; hence, the coordination between all states is crucial. Within the ambit of Global Health Governance, the World Health Organization, is 'the directing and coordinating authority on international health work'. It is mandated, particularly, to stimulate and advance work to eradicate disease. To this end, this article examines, through an in-depth case study, the impact of the ongoing Covid-19 outbreak on the efficiency of the WHO to undertake its mandate during times of emergencies, as prescribed in its legal frameworks. The article addresses this issue from two sides: how the decision-making process has been taken internally within the WHO to control the global outbreak of the Covid-19, and how the WHO interacted with states to ensure compliance with relevant laws and recommendations.

In doing so, this article is divided into four parts. In part I, it introduces the WHO as the main actor in the global health governance, highlighting its main powers and responsibilities. Part II examines the WHO's legal tools, powers and mechanisms to control diseases and discusses whether these are fit and reliable. Part III focuses on the WHO response to the ongoing outbreak of Covid-19 in light of its mandate and powers as provided in the 2005 International Health Regulations. Part IV concludes on the effectiveness of the WHO response to the ongoing crisis and suggests relevant ways for enhancement.
\end{abstract}


This article proposes three principles for improving the WHO response to pandemic outbreaks: a transparent mechanism for conducting all businesses within the WHO, especially decision making; an enforcement mechanism to impose compliance on member states; and a rigorous system to assist states in building their capacities.

Keywords: Coronavirus pandemic, Covid-19, Global Health Governance, World Health Organization, International Health Regulations, Public Health Emergency of International response (PHEIC)

\section{استجابة منظمة الصحة العالمية لوباء فيروس كورونا المستجد (كوفيد - 9 (1): تقييم وفقًا لقواعد القانون الدولي لئي

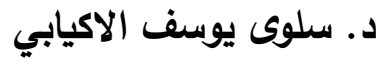 \\ أستاذ مساعد القانون الدولي العام - كلية الحقوق - جامعة الزقازيق}

\section{ملخص}

شكل تفشي وباء فيروس كورونا (كوفيد -9 (1) تهديدًا خطيرًا للمجتمع الدولي وأثر على جميع القطاعات تقريبًا. على الصعيد العالمي، لا يمكن مكافحة تفشي الوباء أو القضاء

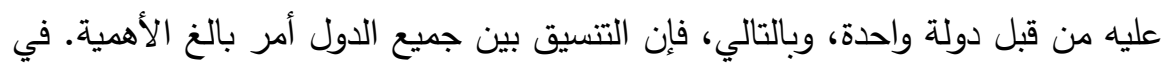
نطاق إدارة الصحة العالمية، تعد منظمة الصحة العالمية "السلطة التوجيهية والتنسيقية بشأن العمل الصحي الدولي"، وهي مكلفة على وجه الخصوص بتحفيز العمل على استئصال المرض ودفع الوباء. وتحقيقا لهذه الغاية، يتناول هذا المقال، من خلال دراسة متعقة، تأثير تفشي فيروس كوفيد 19 على كفاءة منظمة الصحة العالمية في الاضطلاع بمهامها المنوطة بها، على النحو المنصوص عليه في أطرها القانونية خلال أوقات الطوارئ الدولية. ويعالج المقال هذا الموضوع من جانبين: الأول: كيفية صنع القرار داخليًا داخل منظمة الصحة العالمية للسيطرة على تفشي كوفيد 9 (، والثاني: كيفية تفاعل المنظمة مع الدول لضمان الامتثال للقوانين والتوصيات ذات الصلة. 
The WHO Response to the Pandemic Coronavirus (Covid-19) Outbreak: An Evaluation Under the Rule of International Law

Salwa Youssef Elekyabi

مجلة علمية محكمة المجلة القانونية (مجلة متخصصة في الاراسات والبحوث القانونية)

وعلى ذلك، تتقسم هذه المقالة إلى أربعة أجزاء، يتتاول الجزه الأول منزلة منظمة الصحة العالمية باعتبارها الفاعل الرئيسي في نظام الحوكمة الصحية العالمية، مع إبراز سلطاتها ومسؤولياتها الرئيسية في أوقات الطوارئ الدولية. ويفحص الجزء الثاني الأدوات والسلطات والآليات القانونية لمنظمة الصحة العالمية لمكافحة الأمراض وما إذا كانت مناسبة وموثوقة. ويركز الجزء الثالث على استجابة منظمة الصحة العالمية لتشي وباء كوفيد 91 في ضوء ولايتها وسلطاتها على النحو المنصوص عليه في اللوائح الصحية الدولية لعام 0 . . r. ويختتم الجزء الرابع بتقييم فاعلية استجابة منظمة الصحة العالمية للأزمة المستمرة وسبل تعزيزها. وتختتم هذه المقالة باقتراح ثلاثة مبادئ لتحسين استجابة منظمة الصحة العالمية لتفشي الأوبئة، وهي: تطوير آلية شفافة لإدارة جميع الأعمال داخل منظمة الصحة العالمية، ولا سيما صنع القرار، ووضع آلية إنفاذ لفرض الامتثال على الدول الأعضاء، وتطبيق نظام صارم لمساعدة الدول في بناء قدراتها. الكلمات المفتاحية: جائحة فيروس كورونا، كوفيد -9 1، حوكمة الصحة العالمية، منظمة الصحة العالمية، اللوائح الصحية الدولية، طوارئ الصحة العامة للاستجابة الدولية. 


\title{
The WHO Response to the Pandemic Coronavirus (Covid-19)
} Outbreak: An Evaluation Under the Rule of International Law

\author{
Dr. Salwa Youssef Elekyabi \\ Associate Professor, Faculty of Law - Zagazig University*
}

\section{Introduction}

By the time of writing this article, it had been estimated that there have been more than 20 million confirmed cases of Covid-19, including approximately 700 thousand deaths worldwide. ${ }^{1}$ The virus was confirmed by the World Health Organization (WHO) as the agent responsible for the atypical pneumonia, ${ }^{2}$ and was identified as severe acute respiratory syndrome coronavirus 2 (SARS-CoV-2), also 2019-nCoV, widely known as coronavirus disease or Covid-19. ${ }^{3}$ Allegedly, Covid-19 was first detected in early December 2019, in a wet seafood market in Wuhan, China, and within a few months, it rapidly spread in almost every country around the globe, due to its high transmissibility from human-tohuman. ${ }^{4}$

\footnotetext{
* The author would like to thank Dr. Nina A. Razzak for her helpful editing of this article and the anonymous reviewers for their careful reading of this article and their insightful suggestions.

${ }^{1}$ These numbers are as reported to the WHO on 14 of August 2020. For a realtime update on Covid-19 cases. See: The Dashboard of the WHO available at: https://covid19.who.int/ (all websites in this paper has been checked and last visited on 17 August,2020).

${ }^{2}$ [Hereinafter: Covid-19]. For more information about Covid-19, See: 'Whole genome of novel coronavirus, 2019-nCoV, sequenced', Science Daily, 31 January 2020. Available at:

https://www.sciencedaily.com/releases/2020/01/200131114748.htm

${ }^{3}$ Covid-19 pandemic or SARS-CoV-2 is a member of the coronavirus family. It is also known as Novel Coronavirus, because it is different that all previously known Coronavirus family, it hasn't been tested before, there is no vaccines or medication for it. See: Eric E. Johnson \& Theodore C. Bailey, Urgent Legal Lessons from a Very Fast Problem: Covid-19, 73 STAN. L. REV, 2020, p. 1

4 'Coronavirus detected in Wuhan in late December: China', The Economic Times, $\quad 7 \quad$ April $2020 . \quad$ Available at:https://economictimes.indiatimes.com/news/international/world-
} 
The WHO Response to the Pandemic Coronavirus (Covid-19) Outbreak: An Evaluation Under the Rule of International Law

Salwa Youssef Elekyabi

مجلة علمية محكمة

المجلة القانونية (مجلة متخصصة في الاراسات والبحوث القانونية)

On 30 January 2020, the WHO declared Covid-19 a Public Health Emergency of International Concern, and by March 2020, the WHO declared Covid-19 a pandemic. ${ }^{5}$ From that moment, almost everyone's life on earth was affected; as, schools and universities were closed, widespread social distancing was imposed, lockdown of cities and quarantine became the norm, and even domestic travel was restricted. ${ }^{6}$ Dramatically, Covid-19 outbreak has gravely impacted trade, economy, travel, tourism and almost all sectors in every country. ${ }^{7}$ According to a research, these implications could've been mitigated by up to $95 \%$ if suitable and effective actions were taken from the onset of the Covid-19 outbreak. ${ }^{8}$

The WHO response to the ongoing Covid-19 has been criticized by many legal scholars. ${ }^{9}$ According to a legal commentator, the WHO

news/coronavirus-detected-in-wuhan-in-late-december-

china/articleshow/75028126.cms?from $=$ mdr

5 'WHO has been assessing this outbreak around the clock and we're deeply concerned both by the alarming levels of spread and severity and the alarming levels of inaction. We have therefore made the assessment that Covid-19 can be characterized by pandemic', said the WHO Director General Tedros Adhanom Ghebreyesus in a press conference on 11 March 2020. See: China hid the severity of its coronavirus outbreak and muzzled whistleblowers - because it can, VOX, 10 February 2020. Available at: https:/www.vox.com/futureperfect/2020/3/11/21175061/who-declares-coronavirus-covid-19-pandemic

${ }^{6}$ Lawrence O. Gostin, Eric A. Friedman, and Sarah A. Wetter, Responding to Covid-19: How to Navigate a Public Health Emergency Legally and Ethically, Hastings Center Report 50, no. 2 (2020), p.8.

${ }^{7}$ J. Benton Heath, Pandemic and other Health Emergencies, Oxford Handbook of International Law and Global Security (forthcoming), July 27, 2020, Temple University Legal Studies Research Paper No. 2020-12, p.4. Available at: https://ssrn.com/abstract=3574149

${ }^{8}$ Devashsish Giri, Responsibility of China for the Spread of Covid-19: Can China Be Asked to Make Reparations?, JURIST - Student Commentary, April 10, 2020. Available at:https://www.jurist.org/commentary/2020/04/devashsishgiri-china-covid19-reparations/

9 See for example, Eyal Benvenisti, The WHO - Destined to Fail?: Political Cooperation and the COVID-19 Pandemic (June 30, 2020). University of Cambridge Faculty of Law Research Paper No. 24/2020, Available 
has reacted slowly to information about the outbreak of Coronavirus in China and was late in recommending restrictions on travel. ${ }^{10}$ Others have argued that the WHO has abjectly failed to fulfill its mandate. ${ }^{11}$ The government of the United States has accused the WHO of being 'overly deferential to China's misinformation and overly critical of the U.S. travel ban on passengers arriving from China, thereby exacerbating the scale of the crisis in the United States and around the world'. ${ }^{12}$ States has been criticized too for either applying excessive health measures in response to the crisis ${ }^{13}$ or violating the WHO recommendations. ${ }^{14}$ China has been, particularly, accused of obfuscating information and providing inaccurate information to the WHO. ${ }^{15}$ It was sued before the U.S. District Court for the Eastern District of Missouri, in April 2020, for its role in unleashing the Covid-19 pandemic. ${ }^{16}$ This has raised concerns about the powers of the WHO to enforce states to comply with its laws and recommendations. Also, this

at: https://ssrn.com/abstract=3638948, and Mark Eccleston-Turner, Adam Kamradt-Scott, Transparency in IHR emergency committee decision making: the case for reform, BMJ Global Health, August 2020. Available at: https://gh.bmj.com/content/bmjgh/4/2/e001618.full.pdf

${ }^{10}$ Eyal Benvenisti, The WHO - Destined to Fail?: Political Cooperation and the COVID-19 Pandemic, op.cit, p.3

11 Jose E. Alvarez, The WHO in the Age of the Coronavirus (July 13, 2020). NYU School of Law, Public Law Research Paper No. 20-30, p.3. Available at: https://ssrn.com/abstract $=3659572$

${ }^{12}$ Ibid.

${ }^{13}$ Chiara Giorgetti, International Health Emergencies in Failed and Failing States, 44 Geo. J. Int'1 L. 1347, p.15.

14 Armin Von Bogdandy and Pedro A. Villarreal, International Law on Pandemic Response: A First Stocktaking in Light of the Coronavirus Crisis (March 26, 2020). Max Planck Institute for Comparative Public Law \& International Law (MPIL) Research Paper No. 2020-07, p.23. Available at: https://ssrn.com/abstract $=3561650$

15 'Coronavirus: Trump aide claims China guilty of cover-up akin to Chernobyl', The Guardian, available at:https://www.theguardian.com/world/2020/may/24/coronavirus-donald-

trump-adviser-china-who-chernobyl-golf

${ }^{16}$ Paul J. Larkin, Jr., Suing China Over Covid-19, 100 B.U. L. Rev. Online 91, p.2. 
The WHO Response to the Pandemic Coronavirus (Covid-19) Outbreak: An Evaluation Under the Rule of International Law

Salwa Youssef Elekyabi

مجلة علمية محكمة

المجلة القانونية (مجلة متخصصة في الاراسات والبحوث القانونية)

pegs the question about how pandemic diseases are controlled and contained on the global level, in other words, how the international health emergencies are managed within the global health governance.

As envisaged in its constitution, the WHO is mandated to 'the attainment by all peoples of the highest possible level of health. ${ }^{17}$ To achieve this ambitious objective, the WHO was tasked with twenty-two core functions, including to 'stimulate and advance work to eradicate epidemic, endemic and other diseases ...' .18 Further, the WHO has developed the International Health Regulations (IHR) as a key instrument to delineate the organization's response in times of pandemic outbreaks. The purpose of the IHR as defined in article 2 is to "prevent, protect against, control and provide a public health response to the international spread of disease'. Accordingly, the WHO plays a significant role in the sphere of the global health governance.

To this end, this article examines the WHO response to the Covid19 crisis, as per its legal framework, from two sides: how the WHO has acted internally to take decisions to control the global outbreak of the disease, and how it has interacted with states to ensure compliance with relevant laws and recommendations. The article aims at reaching a conclusion on how effective the WHO response to the ongoing crisis has been thus far and how this can be enhanced.

This Article proceeds in four parts. In part I, it begins with exposing the role of the WHO within the 'global health governance'. In this part, the powers and authorities of the WHO in times of health emergencies are investigated. Part II introduces the relevant provisions in the International Health Regulations, as the only international legal instrument applicable in times of

17 The World Health Organization Constitution of 1948, [hereinafter: WHO Constitution], Art.1.

${ }^{18}$ WHO Constitution, Art.2. 
المجلة القانونية (مجلة متخصصة في الدراسات والبحوث القانونية)

(ISSN: 2537 - 0758)

emergencies $^{19}$ and examines whether these provisions are empowering the organization with the needful means to effectively control diseases (fitness of purpose). The discussion herein paves the way for part III, which tracks the WHO response to the Covid19 outbreak and analyzes how the organization has acted to control the largest global pandemic in the $21^{\text {st }}$ Century (fitness for purpose). In this part, the article links the WHO response to the Covid-19 outbreak to its mandate and powers, as provided in its main legal instruments. Finally, Part IV states the arrived conclusion.

\section{The Role of WHO Within the Global Health Governance}

\section{The need for a 'global health governance'}

The term 'global health governance' is a newly emerged concept, which was used for the first time in the 1990s in the field of international relations to indicate the need for international health cooperation between different stockholders. ${ }^{20}$ Since 2002, the term has been widely used in different disciplines including the scholarship of public international law, in which it refers to the rules, norms, institutions, and processes that shape the global health and organize cooperation between divergent stakeholders, to improve global health and narrow health inequalities. ${ }^{21}$ With this meaning, the need for a global health governance was not compelling in early pandemic outbreaks. As early as 1851, with the outbreak of Cholera, cooperation to control this disease was limited to a few states, which convened in Paris during the first International Sanitary Conference, to develop a common

\footnotetext{
${ }^{19}$ J. Benton Heath, Pandemic and other Health Emergencies, op.cit, p.4.

${ }^{20}$ Kelley Lee and Adam Kamradt-Scott, The multiple meanings of global health governance: a call for conceptual clarity, Lee and Kamradt-Scott Globalization and Health 2014, p.2. Available at:

https://globalizationandhealth.biomedcentral.com/track/pdf/10.1186/17448603-10-28

${ }^{21}$ Tsung-Ling Lee, Making International Health Regulations Work: Lessons from the 2014 Ebola Outbreak, 49 Vand. J. Transnat'1 L. 931
}

1702 
The WHO Response to the Pandemic Coronavirus (Covid-19) Outbreak: An Evaluation Under the Rule of International Law

Salwa Youssef Elekyabi

مجلة علمية محكمة

المجلة القانونية (مجلة متخصصة في الاراسات والبحوث القانونية)

framework to control the international spread of diseases. ${ }^{22}$ Back then, the means of communication and transportation between nations were limited and were mainly by sea, so the measures taken to control the disease were limited too and were mainly quarantines of incoming travelers and maritime transportation restrictions. ${ }^{23}$ Although unsuccessful, this experience reinforced the fact that states cannot contain diseases alone and that the coordinated agreement between states is critical for controlling diseases outbreaks.

By the beginning of the $20^{\text {th }}$ century, and with the emergence of international organizations, new entities were established in the field of health. In 1902 and 1907, two international organizations were established, the Pan-American Health Organization (PAHO) and the International Office of Public Health, respectively. Both aimed at disease outbreak control, however their scope of work was limited; for example, the International Office of Public Health activities were limited to the exchange of information, conducting studies and the administration of international conventions. ${ }^{24}$ Within the umbrella of the league of nations, two entities were established: the Health Office in 1923 and the International Office of Epizootics in $1924 .^{25}$ These entities have assumed a role in controlling disease outbreaks and paved the way for establishing a specialized health organization that assumes a global role in health governance. In 1946, the WHO was established as the specialized agency within the United Nations (UN) system, uniquely situated

${ }^{22}$ Ibid.

23 Armin Von Bogdandy and Pedro A. Villarreal, International Law on Pandemic Response: A First Stocktaking in Light of the Coronavirus Crisis, op.cit, p. 3.

${ }^{24}$ Allyn Lise Taylor, Making the World Health Organization Work: A Legal Framework for Universal Access to the Conditions for Health, 18 Am. J. L. and Med. 301, p. 16.

${ }^{25}$ David P. Fidler, The Future of the World Health Organization: What Role for International Law?, 31 Vand. J. Transnat'l L. 1079, p. 5. 
to address international health concerns. ${ }^{26}$ The WHO superseded the International Office of Public Health and integrated the PAHO as one of its six regional offices.

\section{The WHO constitution}

On April 7, 1948, the WHO constitution entered into force. ${ }^{27}$ This constitution depicted the responsibility and the authority of the organization as the principle organization in the health field. The preamble expanded the definition of health to signify 'a state of complete physical, mental, and social well-being and not merely the absence of disease or infirmity'. Within this expansive definition, article 1 prescribed the objective of the WHO as 'the attainment by all peoples of the highest possible level of health'. In fulfilling this ambitious end, the constitution provided the WHO with extensive powers and authorities compared to other former organizations in the field of health such as the Pan American Sanitary Bureau and International Office of Public Health, or any other UN agency. ${ }^{28}$

The WHO was envisaged by its founders as an overarching organization in the health field that coordinates efforts between states and provides them with medical expert advice to eradicate disease. Thus, the organization was designed as a scientifictechnical oriented organization rather than a politically-oriented one as most international organizations are. ${ }^{29}$ These two features, the extensive powers and the scientific-technical approach, happen to be cardinal elements in shaping the WHO response to health emergencies such as the Covid-19 pandemic outbreak.

\footnotetext{
${ }^{26}$ As per the UN charter and the WHO constitution.

${ }^{27}$ Anton Knieling, World Health Organization. In: S. Loue (ed.), Mental Health Practitioner's Guide to HIV/AIDS, p.437.

${ }^{28}$ Tsung-Ling Lee, Making International Health Regulations Work: Lessons from the 2014 Ebola Outbreak, 49 Vand. J. Transnat'l L. 931

${ }^{29}$ Eyal Benvenisti, The WHO - Destined to Fail?: Political Cooperation and the COVID-19 Pandemic, op.cit, p.3
} 
The WHO Response to the Pandemic Coronavirus (Covid-19) Outbreak: An Evaluation Under the Rule of International Law

Salwa Youssef Elekyabi

مجلة علمية محكمة

المجلة القانونية (مجلة متخصصة في الاراسات والبحوث القانونية)

\section{A. Extensive powers to control diseases}

For WHO to achieve its objective, its constitution empowered it as an organization with both normative and directing powers. ${ }^{30}$ With respect to normative powers, the World Health Assembly (WHP), the main governing body of the WHO composed of delegates of 193 state members, has the authority to adopt conventions and agreements ${ }^{31}$ with respect to any matters within the competence of the organization by the majority of two-thirds of members present and voting. ${ }^{32}$ In addition, the WHP 'shall have authority to adopt regulations concerning ... sanitary and quarantine requirements and other procedures designed to prevent the international spread of disease', ${ }^{33}$ these regulations are binding to all member states without requiring ratification. ${ }^{34}$ Under these powers, the WHA adopted conventions such as the Framework convention on Tobacco, and regulations such as the 2005 IHR. Thus, this normative power of the WHA is truly a 'fairly unique lawmaking

30 'Normative powers' refers to the power to approve, through the World Health Assembly, specific regulations that are mandatory for Member States. By contrast, WHO's 'directing powers' encompasses policy directives that suggest, but do not require, that Member States undertake a certain course of action. See Chiara Giorgetti, International Health Emergencies in Failed and Failing States, op.cit, p.11.

${ }^{31}$ See for example; the Framework Convention on Tobacco Control, adopted in May 2003, and entered into force in 2005. Available at http://www.who.int/tobacco/framework/en/

${ }^{32}$ Articles 19 and $60 / \mathrm{a}$ of the WHO constitution. Article $2 / \mathrm{k}$ provides that the WHO will, 'propose conventions, agreements and regulations, and make recommendations with respect to international health matters and to perform such duties as may be assigned thereby to the Organization and consistent with its objectives'. Article 21 states that the WHO shall have authority to adopt regulations concerning 'sanitary and quarantine requirements and other procedures designed to prevent the international spread of disease'.

${ }^{33}$ The WHO Constitution, Art. 21.

${ }^{34}$ The WHO Constitution, Art. 22. 
device in the international system', as described by Professor Allyn Taylor. ${ }^{35}$

With respect to the directing powers, the WHO constitution has bestowed the organization with 'the directing and coordinating authority on international health work' ${ }^{36}$ Further, article 2 of the Constitution outlines twenty-two core functions of the organization, amongst them, "stimulate and advance work to eradicate epidemic, endemic and other diseases ... '; 'establish and maintain effective collaboration with the United Nations, specialized agencies, governmental health administrations, professional groups and such organizations as may be deemed appropriate'; 'furnish appropriate technical assistance and, in emergencies, necessary aid upon the request or acceptance of Governments'; and 'establish and maintain such administrative and technical services as may be required, including epidemiological and statistic services'. Article 2 concludes with a general statement that the WHO should 'generally ... take all necessary action to attain the objective of the Organization'.

\section{B. Scientific-Technical approach}

One of the key features of the WHO is the vibrant scientifictechnical approach. ${ }^{37}$ Unlike the politically-oriented character of most of international organizations, the WHO is distinguished in employing technicians and experts in the medical and health field. All states' representatives in the organization are to be 'chosen from among persons most qualified by their technical competence in the field of health' ${ }^{38}$ Given that unique characteristic, the WHO constitution has placed an emphasis on obtaining information and collecting data. Article 2 enumerates some of the core functions of

35 Allyn Taylor \& Emily Bruemmer, Institutional Transparency and Global Health Lawmaking: Case Study of the International Health Regulations, In Andrea Bianchi and Anne Peters (eds.): Transparency in International Law, Cambridge University Press, (2013).

${ }^{36}$ The WHO Constitution, Art. 2.

${ }^{37}$ Eyal Benvenisti, The WHO - Destined to Fail?: Political Cooperation and the COVID-19 Pandemic, op.cit,p.6.

${ }^{38}$ The WHO Constitution, Art. 11. 
The WHO Response to the Pandemic Coronavirus (Covid-19) Outbreak: An Evaluation Under the Rule of International Law

Salwa Youssef Elekyabi

مجلة علمية محكمة

المجلة القانونية (مجلة متخصصة في الاراسات والبحوث القانونية)

the WHO with relation to information and data collection, inter alia, 'to promote and conduct research in the field of health' and 'to provide information, counsel and assistance in the field of health.'

To sum up, the WHO is the main international organization specialized in the field of health and has a wide objective that involves the attainment of 'the highest possible level of health' with an expanded definition of health. The scientific-technical approach of the organization distinguishes the WHO as an agency grounded in predictability and certainty ${ }^{39}$ and justifies the states' agreement to cede authority for a global organization, the WHO, to act without pre-approval. ${ }^{40}$ Given that all states in the world are states' members in the WHO, and given that it enjoys extensive powers and authorities, it can, hypothetically, impose obligation on states' members and enforce them. Therefore, it lies in the heart of today's global health governance. ${ }^{41}$

\section{The International Health Regulations}

The International Health Regulations (IHR) were first adopted by the WHA in 1969, then they were subject to two amendments in 1973 and 1981. These amendments primarily aimed to refine the list of diseases that are covered by the regulations. ${ }^{42}$ In 1995, the

39 Tsung-Ling Lee, Making International Health Regulations Work, op.cit., p.931.

${ }^{40}$ Eyal Benvenisti, The WHO - Destined to Fail?: Political Cooperation and the COVID-19 Pandemic, op.cit, p.6

${ }^{41}$ As stated by Lee, by establishing the WHO "an international infectious disease control regime grounded in predictability and certainty, thus, was born". Tsung-Ling Lee, Making International Health Regulations Work, op.cit., p.931.

${ }^{42}$ The 1969 IHR was only covering six quarantinable diseases: Cholera, plague, relapsing fever, smallpox, typhus and yellow fever, then reduced to just three: Cholera, plague and yellow fever. See: Morten Broberg, A Critical Appraisal of the World Health, Organization's International Health Regulations, (2005) in Times of Pandemic: It Is Time for Revision, European Journal of Risk Regulation, 2020, vol.11.2, p. 204. The reason for limiting the IHR diseases list 
WHA called for a substantial revision of the Regulations, and with the global outbreak of the Severe Acute Respiratory Syndrome (SARS) in 2002, it became a priority. On the $23^{\text {rd }}$ of May 2005, the revised IHR was adopted by the WHA, widely known as the 2005 IHR, and on 15 June 2007 it was entered into force. ${ }^{43}$ Unlike its predecessors, the 2005 IHR is not confined to certain diseases, but rather applicable to any threat to the public health and any case of spread of diseases on the international level. This is reflected in article 2 of the regulations, which states that the purpose of the IHRs is to 'prevent, protect against, control and provide a public health response to the international spread of disease'.

The 2005 IHR is legally binding to all member states of the WHO, as it is adopted by the WHA pursuant to its authority to adopt binding regulations. ${ }^{44}$ Internationally, it is the key instrument on how to deal with pandemics from the very beginning till the end; it places obligations on the WHO to prevent, protect against and control any international spread of disease, and enables the WHO to issue recommendations to all member states with this regard. In turn, states are obliged, as per the regulations, to notify the WHO with information about any suspicious cases that may constitute an international health concern and to comply with the WHO recommendations. Thus, coordinating the international response to a disease outbreak is the responsibility of the $\mathrm{WHO}$, as the main actor in the global health governance; however, this can't be achieved without the assistance of states and their compliance with the WHO laws and recommendations.

to only three diseases, was that scientists believed, at that time, that these three are the only diseases that pose international threat. This perspective has been changed in modern days. See: Mark J. Volansky, Achieving Global Health: A Review of The World Health Organization's Response, 10 Tulsa J. Comp. \& Int'l L. 223, p.10.

${ }^{43}$ See: The International Health Regulations, p.1. available at: https://apps.who.int/iris/bitstream/handle/10665/246107/9789241580496eng.pdf? sequence $=1$

${ }^{44}$ The WHO Constitution, Art. 21. 
The WHO Response to the Pandemic Coronavirus (Covid-19) Outbreak: An Evaluation Under the Rule of International Law

Salwa Youssef Elekyabi

مجلة علمية محكمة

المجلة القانونية (مجلة متخصصة في الاراسات والبحوث القانونية)

Accordingly, the following part analyses the IHR-related provisions in a sequence organized from three angles, starting with notifying the WHO about any suspicious event, then how the WHO should handle this notification and take decision with regard to any health emergency of international concern, and lastly the scope of health measures that should be recommended by the WHO or implemented by states. This part aims at introducing the main provisions which are applicable to the ongoing Covid-19 situation and clarifying any shortcomings in the IHR as well as the main strengths. Thus, this part is intended to pave the way for the discussions that will follow in the later parts.

\section{Information-Sharing}

In a time of a pandemic outbreak, timely and accurate information is of essence to the WHO, and as the WHO doesn't possess the capability to collect data on its own, it depends entirely on the states' cooperation. So, obliging states to provide the WHO with timely and accurate information is a cardinal pillar in shaping the international response to disease outbreaks.

Part II of the IHR details how states can share information with the WHO in a logical sequence. It begins with the obligation for states to build their capacities in relation to detecting, assessing, notifying and reporting events in accordance with the IHR. ${ }^{45}$ This is in addition to designating a national focal point for direct contact with the WHO and 'the responsible authority' for the implementation of health measures as dictated in accordance with the IHR. ${ }^{46}$ Then, the IHR clarifies that states are obliged to notify the WHO, within 24 hours of assessment of public health information, of 'all events which may constitute a public health emergency of international concern within its territory'. ${ }^{47}$ Also, a state should communicate with the WHO if it has noticed 'an

${ }^{45}$ The IHR, Art. 5.

${ }^{46}$ The IHR, Art. 4.

${ }^{47}$ The IHR, Art. 6. 
unexpected or unusual public health event within its territory', and has suspected that it may constitute a public health emergency of international concern. ${ }^{48}$ In both cases, the concerned state shall continue to communicate and update the WHO with 'timely, accurate and sufficiently detailed public health information available to it on the notified event'. The IHR goes far in article 8 and asks states to keep the WHO informed with events, even if they do not fall within the description of article 6 , and to consult with the WHO about any health measure in this regard.

Accordingly, it is abundantly clear that sharing information about public health events with the WHO is a legally binding obligation, whether it constitutes a public health emergency, or is just an unexpected or unusual event. Even if it was a mere public health event, it is important to keep the WHO informed. However, in practice, it has been noticed that some states, in which the disease originated, are lacking sufficient resources to detect, assess, notify and report suspicious events to the WHO. The infrastructure of many member states, especially the developing countries in which most of global outbreaks originate, is limited and usually ineffective. So, these states may not realize when the disease originates and subsequently may fail to notify the WHO of it in a timely manner. ${ }^{49}$ In best cases, these states will take time to notify the WHO with the necessary information; by then, the disease may have already spread uncontrollably. ${ }^{50}$ According to one report, as of 2011, only 74 states out of 194 state parties to the WHO had developed national plans to meet the IHR capacity requirements. ${ }^{51}$ Further, the Review Committee, which was established to review the WHO response pursuant to the new IHR 2005 in the H1N1

\footnotetext{
${ }^{48}$ The IHR, Art. 7.

${ }^{49}$ Mark J. Volansky, Achieving Global Health: A Review of The World Health Organization's Response, op.cit, p.13

${ }^{50}$ Morten Broberg, A Critical Appraisal of the World Health, Organization's International Health Regulations, op.cit, p. 208.

${ }^{51}$ See: Accelerating Implementation of the International Health Regulations (2005), WHO (2013), available at:

http://www.who.int/ihr/publications/WHO_HSE_GCR_2013_5en.pdf?ua=1
} 
The WHO Response to the Pandemic Coronavirus (Covid-19) Outbreak: An Evaluation Under the Rule of International Law

Salwa Youssef Elekyabi

مجلة علمية محكمة

المجلة القانونية (مجلة متخصصة في الاراسات والبحوث القانونية)

crisis, has warned after the 2009 H1N1 influenza outbreak that the world is ill-prepared to respond to a global health emergency, and urged for the full implementation of the IHR. ${ }^{52}$ This, in the author's view, requires from the WHO to focus on assisting states to build their capacities with regard to detecting and assessing diseases in their territory.

Moreover, it has been noted that some states, despite their capabilities to notify the WHO in a timely and accurate manner, either delay the sharing of information with the WHO or suppress information to save their public interests or image. ${ }^{53}$ For example, with the onset of the SARS outbreak, before adopting the 2005 IHR, China was accused of suppressing information about the virus, delaying in sharing early information and of being generally uncooperative with the WHO. ${ }^{54}$ While the first case was identified in November 2002, China officially acknowledged and reported the existence of the virus to the WHO on 11 February 2003. At that time, China feared the damaging of its local image, so it tried to contain the disease domestically but failed. ${ }^{55}$

Despite the lack of cooperation and resistance by many states to cooperate, the WHO response to the aftermath of the SARS crisis was hailed as successful and efficient by many commentators and

52 WHO, Report of the Review Committee on the Functioning of the International Health Regulations (2005) in Relation to Pandemic (H1N1) 2009, U.N. Doc. P 18 A64/10 (May 5, 2011), [hereinafter: The Review Committee]. Available at: http://apps.who.int/gb/ebwha/pdf files/WHA64/A64 10-en.pdf.

${ }^{53}$ Morten Broberg, A Critical Appraisal of the World Health, Organization's International Health Regulations, op.cit, p. 206

54 Armin Von Bogdandy and Pedro A. Villarreal, International Law on Pandemic Response: A First Stocktaking in Light of the Coronavirus Crisis, op.cit, p.23.

${ }^{55}$ Chenglin Liu, Regulating SARS in China: Law As an Antidote? (2005). Washington University Global Studies Law Review Vol. 4, 2005, Available at: https://ssrn.com/abstract=2892011 
المجلة القانونية (مجلة متخصصة في الدراسات والبحوث القانونية)

(ISSN: 2537 - 0758)

legal scholars. ${ }^{56}$ The reason was the decisive and bold decisions taken by its political rounded Director-General Gro Harlem Brundtland. ${ }^{57} \mathrm{He}$ acted promptly, and during a few weeks, the WHO had succeeded in obtaining all the needful information from every available resource and issued public advisories. ${ }^{58}$ It, further, sent teams of experts into infected countries to ensure that they were following effective policies. Additionally, it resorted to public shaming of China and even issued an ultimatum to elicit its cooperation. $^{59}$

During the time of the SARS outbreak, the 1969 IHR was in force, though the negotiations to amend it were in process. So, the WHO Director-General actions and the overall WHO response to the SARS crisis, although being beyond the scope of the 1969 IHR, gave impetus to the negotiations and inspired the deliberations for revising the 1969 IHR from different sides. This is including the need to approach the WHO for greater access to information, such as non-state-based information, to avoid any dilatory in providing information to the WHO, especially when the concerned state is shown to be uncooperative. ${ }^{60}$ This was reflected in articles 9 and 10 of the 2005 IHR, which enabled the WHO to receive information from sources 'other than notifications or consultations'; these may include information received from nonstates entities, individuals, or social media. In such instances, the WHO shall assess this information and then verify it from the

\footnotetext{
${ }^{56}$ Eyal Benvenisti, The WHO - Destined to Fail?: Political Cooperation and the COVID-19 Pandemic, op.cit, p.7

${ }^{57}$ Gro Harlem Brundtland was formerly Norway's Prime Minister.

${ }^{58}$ Information was reported to the WHO by individuals and non-governmental entities. WHO then verified those reports with China and requested more information before declaring PHEIC. Chiara Giorgetti, International Health Emergencies in Failed and Failing States, op.cit, p.8.

${ }^{59}$ David P. Fidler, Governance and The Globalization of Disease (2004), pp.7173.

${ }^{60}$ Armin Von Bogdandy and Pedro A. Villarreal, International Law on Pandemic Response: A First Stocktaking in Light of the Coronavirus Crisis, op.cit, p.7
} 
The WHO Response to the Pandemic Coronavirus (Covid-19) Outbreak: An Evaluation Under the Rule of International Law

Salwa Youssef Elekyabi

مجلة علمية محكمة

المجلة القانونية (مجلة متخصصة في الاراسات والبحوث القانونية)

concerned state. ${ }^{61}$ When receiving information that might pose a public health emergency of international concern, the WHO shall offer to collaborate with the concerned state; however, if such states proved to be uncooperative, the WHO may share such information with other states. ${ }^{62}$ In all cases that pose a public health risk, the WHO is obliged to send to all states, without delay, any public health information that may be deemed necessary to enable them to respond to such situations. This information may include any information received by notification or consultation as well as other information received from any source. ${ }^{63}$

Undoubtfully, the IHR included all the possible provisions to highlight the importance of information sharing about any suspicious event in a timely and accurate manner. The establishing of a focal point and the capacity building requirements are relevant too. However, according to the author, two shortcomings are obviously alarming: the states' inability to notify and their unwillingness to notify. With respect to the states' inability, it is crucial that the WHO should devote part of its budget to assist states in building their capacity with regard to detecting, assessing and reporting international health emergencies to the WHO. The WHO should deploy professionals who are capable of intervening at very short notice, whenever and wherever the need arises. With respect to states' unwillingness to notify the WHO, the IHR does not include any provisions to enforce states to comply with the regulations; so, legally, this should be amended to include incentives for states to elicit them to comply with the IHR, as well as, sanctions on the non-complying ones. In all, the author concurs with the view that incompliance with the provisions of sharing

${ }^{61}$ The IHR, Art.9/1.

${ }^{62}$ The IHR, Art.10/4.

${ }^{63}$ The IHR, Art. 12. 
information with the WHO undermines the effectiveness of the overall IHR. ${ }^{64}$

\section{Declaring a Public Health Emergency of International Concern}

The 2005 IHR has empowered the WHO Director-General (DG) with the authority to declare an event a public health emergency of international concern (PHEIC). ${ }^{65}$ As per the regulations, the PHEIC means 'an extraordinary event, which is determined to constitute a public health risk to other states through the international spread of disease and to potentially require a coordinated international response'. The event is defined as 'a manifestation of disease or an occurrence that creates a potential for disease'.

When the two definitions are read together, the following can be deduced. First, the definition states that the PHEIC is declared based on whether declaring an event a PHEIC constitutes a 'risk' to other states and whether it 'potentially' requires a coordinated response. By using the terms 'risk' and 'potentially', it is clear that declaring an event a PHEIC is based on doubt or probability. This, in the author's view, means that the DG can declare an event a PHEIC in cases where the DG has only little information about an event, which includes cases of insufficient cooperation by member states, or where the information available to the DG are obtained from sources other than states. This is conforming with article 12, which states that the DG decision to declare a PHEIC should be based on information, that includes the information received by states, the available scientific evidence, experts' advice, different

\footnotetext{
${ }^{64}$ Chiara Giorgetti, International Health Emergencies in Failed and Failing States, op.cit, p. 21

${ }^{65}$ Since the adoption of the 2005 IHR, WHO Director-Generals have declared a PHEIC six times: H1N1 influenza in 2009; wild poliovirus in 2014; the West African Ebola outbreak also in 2014; the Zika outbreak in the Americas of 2016; the Ebola outbreak in the Democratic Republic of the Congo (DRC) in 2019; and the 2020 COVID-19 pandemic. See: Armin Von Bogdandy and Pedro A. Villarreal, International Law on Pandemic Response: A First Stocktaking in Light of the Coronavirus Crisis, op.cit, p.23.
} 
The WHO Response to the Pandemic Coronavirus (Covid-19) Outbreak: An Evaluation Under the Rule of International Law

Salwa Youssef Elekyabi

مجلة علمية محكمة

المجلة القانونية (مجلة متخصصة في الاراسات والبحوث القانونية)

risk assessment of the disease, as well as information in related decision instruments. ${ }^{66}$

Second, the definition states that the event constitutes a public risk to 'other states through the international spread of disease' and 'require a coordinated international response'. These expressions widen the scope of the 'event' to include any event that goes beyond the capabilities of one state and requires the coordination between states to prevent its spread. Accordingly, it is not necessarily that the disease is being classified as 'pandemic', though it is inclusive in the meaning. Also, this means that the PHEIC may be declared on an outbreak affecting one state, or limited number of states, as well as global pandemics that affect a large number of states. ${ }^{67}$

As previously mentioned, the WHO response to the aftermath of the SARS crisis was distinguished by the bold decisions taken by the DG Gro Harlem Brundtland, who was also a seasoned politician. Despite that the response was considered at that time by scholars and legal commentators as being effective, ${ }^{68}$ the DG response was criticized later as having been acted beyond its mandate. ${ }^{69}$ This incident gave rise to tensions between states and pushed the IHR negotiations towards limiting the level of autonomy exhibited by the DG during times of health emergencies. Consequently, a new mechanism was created in the 2005 IHR, which suggests that the DG may establish an emergency committee

${ }^{66}$ The IHR, Art. 12/4. See also, J. Benton Heath, Global Emergency Power in the Age of Ebola, 57 Harv. Int'1 L.J. 1, p.19.

${ }^{67}$ Armin Von Bogdandy and Pedro A. Villarreal, International Law on Pandemic Response: A First Stocktaking in Light of the Coronavirus Crisis, op.cit, p.12.

${ }^{68}$ Eyal Benvenisti, The WHO - Destined to Fail?: Political Cooperation and the COVID-19 Pandemic, op.cit, p.7

${ }^{69}$ David P. Fidler, Governance and The Globalization of Disease, op.cit., pp.95-96. 
on an ad-hoc basis to obtain its technical-scientific advice before deciding to declare an event a PHEIC. ${ }^{70}$

The members of the Emergency Committee (EC) should be selected from the pre-existing IHR 'Expert Roster', based on their experience and expertise in the field, considering the equitable geographical representation. However, the IHR Roster of Experts was criticized for lacking sufficient regional diversity, as noted from the 2019 report of the World Health Assembly. ${ }^{71}$ The power of composing an EC rests on the WHO Director-General; yet, the affected state should nominate at least one expert member. ${ }^{72}$

The DG decision to summon an EC is purely unipersonal. In other words, the DG enjoys full discretion to decide whether to establish such a committee, which reflects the pure consultative nature of the Committee. ${ }^{73}$ Therefore, their views are not binding to the DG, and although never happened, he can side their views and enact his own. In practice, the DGs, to date, have lent the Committee's advice full attention. ${ }^{74}$ As per the IHR, the Committee's tasks are limited to three issues, which are: whether an event constitutes a PHEIC, the termination of a PHEIC, and consultations with regard to the temporary recommendations.

Apparently, resorting to an expert committee with regard to public health emergency decisions and recommendations is adding another layer of certainty and scientific precision to the WHO decision-making process. However, the EC practices have shown

70 Eccleston-Turner M, Kamradt-Scott A Transparency in IHR emergency committee decision making: the case for reform BMJ Global Health 2019. Available at: https://gh.bmj.com/content/4/2/e001618.

71 Armin Von Bogdandy and Pedro A. Villarreal, International Law on Pandemic Response: A First Stocktaking in Light of the Coronavirus Crisis, op.cit, p.20.

${ }_{72}^{72}$ Article 48 details the formation and scope of work for such a committee.

${ }^{73}$ Chiara Giorgetti, International Health Emergencies in Failed and Failing States, op.cit, p. 19.

${ }^{74}$ Armin Von Bogdandy and Pedro A. Villarreal, International Law on Pandemic Response: A First Stocktaking in Light of the Coronavirus Crisis, op.cit, p.13 
The WHO Response to the Pandemic Coronavirus (Covid-19) Outbreak: An Evaluation Under the Rule of International Law

Salwa Youssef Elekyabi

مجلة علمية محكمة

المجلة القانونية (مجلة متخصصة في الاراسات والبحوث القانونية)

that the IHR lacks important details with regard to the EC processes. First, the EC processes in conducting businesses are lacking transparency. The EC deliberations are not available to the public. The WHO only publishes the outcome with minor or no justification. Even the names of the expert members of the EC were not published or shared until $2011 .^{75}$ Consequently, the author agrees with the argument that 'any concerns regarding the transparency of IHR EC processes undermine the decisions reached, the legitimacy of those decisions and their processes and, by association, the IHR 2005 and the treaty's custodian, the WHO'. ${ }^{76}$ Second, the EC's official statements are lacking consistency. In one statement, it declared a pandemic to have 'very high risk of regional spread', though it provided that declaring PHEIC had 'no added benefit'. Third, there is no room for dissenting opinion within the committee's statements, this was notable in its recent statement of 23 January 2020 with respect to Covid-19, as the statement referred to 'divergent views' among the members of the Committee, without explanatory details. ${ }^{77}$

According to one commentator, these critiques might be justified by the urgency and the immediate nature of the emergency committee's advice. In this way, it may be unpractical to delay their advice until all voices are heard or until consensus is reached. So, in such cases 'the benefits of rapid decision-making can justify

${ }^{75}$ This was changed in 2011 on the basis that 'The Organization ... recognized that it requires greater transparency to maintain the trust of the public' (WHO, p 119)

76 Eccleston-Turner M, Kamradt-Scott, Transparency in IHR emergency committee decision making: the case for reform, BMJ Global Health, August 2020. Available at: https://gh.bmj.com/content/bmjgh/4/2/e001618.full.pdf

${ }^{77}$ World Health Organization, Statement on the meeting of the International Health Regulations (2005) Emergency Committee regarding the outbreak of novel coronavirus (2019-nCoV). Available at: https://bit.ly/2WCiRq2

1717 
costs in inclusiveness' ${ }^{78}$ yet, the author is of the opinion that more detailed explanation on why a PHEIC was declared or adding the dissenting opinion to the statement would not affect the urgency of the EC's advice and, conversely, would enhance trust in the Organization and increase transparency.

\section{Health Measures}

Health measures are defined in article 1 of the IHR as 'procedures applied to prevent the spread of disease or contamination'. Within this meaning, the IHR gave the WHO the authority to issue recommendations to exhort states to adopt certain health measures. In addition, it allowed states from their side to apply additional health measures. Under the title 'recommendations', part III of the IHR comprises two types of recommendations: temporary recommendations and standing recommendations, each in a separate article, in addition to two more articles on: criteria of recommendations and recommendations with respect to persons, baggage, cargo, containers, conveyances, goods and postal parcels.

The WHO recommendations are nonbinding; ${ }^{79}$ although, they have a significant impact on economy, trade and tourism. Even on the political level, some recommendations may impose political pressure on states to provide certain health services. ${ }^{80}$

With respect to the temporary recommendations, these are riskspecific and timed with a period of three months from the issuance date, after which they automatically expire; yet, they may be modified or extended for additional periods of up to three months. ${ }^{81}$ The standing recommendations are implemented on a routine or periodic basis and may be modified or terminated as appropriate. These include the appropriate measures to be applied

78 Armin Von Bogdandy and Pedro A. Villarreal, International Law on Pandemic Response: A First Stocktaking in Light of the Coronavirus Crisis, op.cit, p.13

${ }^{79}$ The IHR, Art.1.

${ }^{80} \mathrm{~J}$. Benton Heath, Global Emergency Power in the Age of Ebola, op.cit, p.20.

${ }^{81}$ Chiara Giorgetti, International Health Emergencies in Failed and Failing States, op.cit, p. 19 
The WHO Response to the Pandemic Coronavirus (Covid-19) Outbreak: An Evaluation Under the Rule of International Law

Salwa Youssef Elekyabi

مجلة علمية محكمة

المجلة القانونية (مجلة متخصصة في الاراسات والبحوث القانونية)

for specific ongoing public health risks at certain international airports, ports, or ground crossings. ${ }^{82}$ The DG has the power to issue temporary recommendations, after consulting the EC, ${ }^{83}$ to be implemented by all member states, not only the affected state(s), even in the absence of a member state agreement. ${ }^{84}$

The temporary recommendations normally include health measures to be applied by member states to prevent the spread of diseases or to contaminate them. These health measures may include placing suspect persons under public health observation; implementing quarantine for suspect persons; tracing the contacts of affected persons; refusing entry of suspected and affected persons to states' territories. ${ }^{85}$ However, it has been noted that implementing health measures in states may have serious implications on other law disciplines such as human rights law, trade law, etc. For example, some commentators have opined that tracing the contacts of affected persons is an invasive measure, because this may involve using personal data taken from mobile phones. Therefore, this measure could be discharged especially that the language of the IHRs 'may include the following' permits. ${ }^{86}$ Thus, this measure seems to be inadvisable in a number of states including Germany, although it is applied in for example South Korea. ${ }^{87}$

In addition to health measures recommended by the WHO, the IHR recognized states' right to apply additional health measures domestically, provided that states must report their actions to the WHO, justify the higher degree of restrictiveness and be based on

\footnotetext{
${ }^{82}$ The IHR, Art. 16.

${ }^{83}$ The IHR, Art. 48/1/c.

${ }^{84}$ The IHR, Art. 15.

${ }^{85}$ The IHR, Art. 18.

${ }^{86}$ Armin Von Bogdandy and Pedro A. Villarreal, International Law on Pandemic Response: A First Stocktaking in Light of the Coronavirus Crisis, op.cit, p.8

${ }^{87}$ Mark Zastrow, South Korea is reporting intimate details of COVID-19 cases: has it helped?, Nature News, 18 March 2020. Available at: https://www.nature.com/articles/d41586-020-00740-y .
}

$1719)$ 
المجلة القانونية (مجلة متخصصة في الاراسات والبحوث القانونية)

(ISSN: 2537 - 0758)

scientific evidence. ${ }^{88}$ These three restrictions are intended to balance two conflictive rights and interests: the states right to impose strict restrictive measures on the national level to contain a pandemic for the purpose of protecting the public health interest, and the individual rights and freedoms as well as any other private interests, which are also worthy of respect. In other words, it is acceptable that the right to live transcends other rights and freedoms, yet, restrictions to preserve the right to life should be justified and commensurable, to ensure that other rights and freedoms are not arbitrarily confined.

The balance between conflicting rights and freedoms is evident throughout the related provisions in the IHR. Articles 24 and 25 recognize the states' right to control the conveyances and the conveyances operators and ensure their compliance with the IHR measures, as well as any other measures imposed by national authorities. However, article 26 prevents the application of any health measures to a civilian lorry, train or coach that are not coming from an area affected by a disease, but rather has passed through an affected territory without embarking, disembarking, loading or discharging. This doesn't include the conveyance, which is coming from an affected area or embarking passengers in such areas. Also, article 31 recognizes the right of states to require 'medical examination, vaccination or other prophylaxis' as a condition for travelers before entry to their territories. However, this right is subject to article 32 , which mandates states to respect the travelers' 'dignity, human rights and fundamental freedoms and minimize any discomfort or distress associated with such measures'. As per part VI of the IHR, states may require health documents from travelers before entry into their territories; yet, states are confined with the types of documents as stated in the IHRs or the recommendations issued by the WHO. No health documents, other than those, should be requested by states. In addition, states should not charge international travelers, except

${ }^{88}$ Morten Broberg, A Critical Appraisal of the World Health, Organization's International Health Regulations, op.cit, p. 206 
The WHO Response to the Pandemic Coronavirus (Covid-19) Outbreak: An Evaluation Under the Rule of International Law

Salwa Youssef Elekyabi

مجلة علمية محكمة

المجلة القانونية (مجلة متخصصة في الدراسات والبحوث القانونية)

travelers seeking temporary or permanent residence, for any costs of health measures such as the cost of quarantine, vaccination or other prophylaxis or 'any medical examination... to ascertain the health status'.

Generally, the IHR requires that states shall, when applying any health measures, apply them in transparent and non-discriminatory manner and without delay. ${ }^{89}$ Examinations of health measures taken by states in times of emergencies, show, generally, weak compliance with the IHR and blunt violations of the WHO recommendations. ${ }^{90}$ In turn, the IHR has no provisions to force states to comply with the IHR or the WHO recommendations. This has also been confirmed by the Review Committee too, as it explained that the most important shortcoming of the IHR is that it "lacks enforceable sanctions". 91 From another perspective, the decision-making processes inside the WHO are centralized in the hand of the DG and a selected expert committee with limited representation of the affected state. This casts away states from taking a role in the global health governance and concentrates the authority in the hand of an organization that lacks the ability to enforce compliance amongst states. ${ }^{92}$

\section{The WHO response to the outbreak of Covid-19 Information Sharing}

It is presumed that the Covid-19 virus was first detected in the lung of an infected old man as early as 27 December 2019, when the results showed SARS coronavirus-like illness. ${ }^{93}$ Yet, according to a

\footnotetext{
${ }^{89}$ The IHR, Art. 42.

90 Morten Broberg, A Critical Appraisal of the World Health, Organization's International Health Regulations, op.cit, p. 206

91 Chiara Giorgetti, International Health Emergencies in Failed and Failing States, op.cit, p.20.

92 J. Benton Heath, Global Emergency Power in the Age of Ebola, op.cit, p.23.

93 How early signs of the coronavirus were spotted, spread and throttled in China, The Straits Times, 28 February 2020. Available at:
} 
study conducted by Chinese scientists, which was published in a reputable medical journal (the Lancet), the first Covid-19 patient was identified on 1 December 2019. ${ }^{94}$

On 30 December 2019, Dr. Li Wenliang of Wuhan Central Hospital shared, through one of the popular social media applications in China, a post about a new SARS-like disease that he noticed after examining seven cases. ${ }^{95}$ Four days later, he was summoned by the Public Security Bureau for 'making false comments' that 'severely disturbed the social order' and was compelled to sign a self-criticism letter. ${ }^{96}$ On top of that, the Chinese police charged Dr. Wenliang along with eight others for publishing and sharing rumors. ${ }^{97}$

On 3 January, the Chinese National Health Commission 'ordered institutions not to publish any information related to the unknown

https://www.straitstimes.com/asia/east-asia/how-early-signs-of-the-

coronavirus-were-spotted-spread-and-throttled-in-china

94 The study was conducted by a group of top scientists in China and published on 21 February 2020. It refers to cases detected on 8 December and earlier, it also suggested that SARS-CoV-2 can be transmitted from human-to-human. See: Fact Check: China's Official Coronavirus Timeline Starts Out Weeks Too Late, Xinhua News, April 6, 2020. Available at: https://www.voanews.com/science-health/coronavirus-outbreak/fact-checkchinas-official-coronavirus-timeline-starts-out

95 The post was shared on 'Weibo', a Facebook-like platform, stating that the Severe Acute Respiratory Syndrome is back. See: China arrested 8 for spreading 'hoaxes' about what is now known as coronavirus. What happened to them?, Poynter, 23 January 2020. Available at: https://www.poynter.org/factchecking/2020/the-2019-coronavirus-virus-lands-in-the-u-s-after-killing-17and-taking-eight-to-prison/. For more, see also: Paul J. Larkin, Jr., Suing China Over Covid-19, op.cit, p. 16.

96 Dr. Wenliang was one of eight people who were arrested for "spreading rumors". It is worth mentioned that later the Local authorities later apologized to Dr Li. See: Li Wenliang: Coronavirus death of Wuhan doctor sparks anger, BBC News, 7 February 2020. Available at: https://www.bbc.com/news/worldasia-china-51409801

97 See: China arrested 8 for spreading 'hoaxes' about what is now known as coronavirus. What happened to them?, Poynter, 23 January 2020. https://www.poynter.org/fact-checking/2020/the-2019-coronavirus-virus-landsin-the-u-s-after-killing-17-and-taking-eight-to-prison/

1722 
The WHO Response to the Pandemic Coronavirus (Covid-19) Outbreak: An Evaluation Under the Rule of International Law

Salwa Youssef Elekyabi

مجلة علمية محكمة

المجلة القانونية (مجلة متخصصة في الاراسات والبحوث القانونية)

disease and ordered labs to transfer any samples they had to designated testing institutions, or to destroy them'. ${ }^{98}$ By that time, the Wuhan Institute of Virology had identified and mapped the genome sequence of the novel coronavirus; yet, nothing was announced formally about the virus from the Chinese authorities' side. ${ }^{99}$ On 9 January 2020, the Chinese health authority officially declared that the Novel Coronavirus was behind Wuhan's viral pneumonia, and on 12 January 2020, it shared with the WHO the virus's genomic sequence. ${ }^{100}$ By that time, the Chinese authorities had not revealed any information about the human-to-human transmissibility of the virus; they even reported formally, on 15 January 2020, that they had not found evidence of human-tohuman transmission of the Novel Coronavirus. ${ }^{101}$ On 20 January 2020, it was confirmed by a Chinese doctor, during a TV show, that the new virus is highly transmissible between humans. ${ }^{102}$ On

${ }^{98}$ See: Fact Check: China's Official Coronavirus Timeline Starts Out Weeks Too Late, Xinhua News, April 6, 2020. Available at: https://www.voanews.com/science-health/coronavirus-outbreak/fact-checkchinas-official-coronavirus-timeline-starts-out

${ }^{99}$ See: DNA sleuths read the coronavirus genome, tracing its origins and looking for dangerous mutations, STAT News, 24 January 2020. Available at: https://www.statnews.com/2020/01/24/dna-sleuths-read-coronavirus-genometracing-origins-and-mutations/

${ }^{100}$ See: Whole genome of novel coronavirus, 2019-nCoV, sequenced, Science Daily, 31 January 2020. Available at:

https://www.sciencedaily.com/releases/2020/01/200131114748.htm.

${ }_{101}$ Dr. Lucas Bergkamp, States liability for failure to Control the COVID-19 Epidemic - International and Netherlands Law, Accepted Manuscript for European Journal of Risk Regulation as part of the Cambridge Coronavirus Collection, published online on 2 April 2020. Available at: https://www.cambridge.org/core/services/aop-cambridgecore/content/view/5250CAA5A15C0D9FB9EA490404BA1AE4/S1867299X2 0000215a.pdf/state_liability_for_failure to control the covid19_epidemic int ernational and dutch law.pdf

${ }^{102}$ How early signs of the coronavirus were spotted, spread and throttled in China, The Straits Times, 28 February 2020. Available at: 
24 January 2020, the WHO announced that the Novel Coronavirus can be transmitted from one individual to another.

In light of these facts, three key issues related to information sharing by states are apparent: the suppressing of information, the delay in announcing information, and the provision of inaccurate information. With respect to suppressing information, it has been noted that disclosing information about diseases harms states on various levels. On the economic level, the Peruvian economy, as an example, was affected when the government declared the outbreak of Cholera in 1991. This is due to the fact that this declaration led the international community to ban imports from Peru, which led to serious adverse repercussions on the country's economy. ${ }^{103}$ Politically, declaring outbreaks of diseases may cause uncontrolled chaos. For example, when the Indian government reported the outbreak of the pneumonic plague in 1994, many people tried to escape from the infected city, causing panic and confusion between citizens. On the military level, declaring the spread of diseases among troops can lower their morale and show low troop readiness. So, it is unsurprising that the government of the United States had issued a reservation, when the 2005 IHR was adopted, affirming that 'any notification that would undermine the ability of the U.S. Armed Forces to operate effectively in pursuit of U.S. national security interests would not be considered practicable'. ${ }^{104}$

Thus, states have had different reasons to opt not to declare the outbreak of diseases in their territories and to prefer to contain them domestically. With regard to the ongoing Covid-19 outbreak, China was accused of obfuscating early information about the virus. The Chinese position in this regard was similar to its position at the time of the global outbreak of SARS, which was caused by

https://www.straitstimes.com/asia/east-asia/how-early-signs-of-thecoronavirus-were-spotted-spread-and-throttled-in-china

103 A. Louis Evans, Confronting Global Pandemics: Responding to A State's Refusal of International Assistance in a Pandemic, 34 Conn. J. Int'1 L. 1, Fall 2018 , p. 7 .

${ }^{104}$ Ibid. 
The WHO Response to the Pandemic Coronavirus (Covid-19) Outbreak: An Evaluation Under the Rule of International Law

Salwa Youssef Elekyabi

مجلة علمية محكمة

المجلة القانونية (مجلة متخصصة في الاراسات والبحوث القانونية)

an unknown coronavirus (SARS-Cov) in 2002. ${ }^{105}$ SARS was first identified on November 16, 2002 in Guangdong, south China. By June 2003, the disease had infected around five-thousand and caused deaths to 329 people in China, with an economic loss of approximately $\$ 18$ billion. Soon, the virus spread to twenty-seven countries and infected around eight thousand people worldwide. ${ }^{106}$ Back then, China took about five months to report the disease to the WHO. It was then presumed that China feared stigmatizing its local image and so it tried to contain the disease domestically without public announcement. ${ }^{107}$ In the context of Covid-19, notoriously, China was not the only state that concealed information about the outbreak; reports indicate that Austria and Netherland ignored Covid-19 outbreaks too to save their image and to avoid the potential harm on tourism and trade. ${ }^{108}$

Delaying the provision of information to the WHO has surged sharp debate and accusations between the US and China. China has claimed that it had shared every bit of information with the WHO in a timely and transparent manner, 'since the onset of the epidemic'. ${ }^{109}$ Contrary to that claim, the White House accused china of suppressing information for at least a month after

105 SARS was identified in a southern province in China as early as 16 November 2002, then it spread in 27 countries. The WHO declared SARS an epidemic in March of 2003. See: Chenglin Liu, Regulating SARS in China: Law As an Antidote?, Washington University Global Studies Law Review, Vol.4.8, p.84.

106 Armin Von Bogdandy and Pedro A. Villarreal, International Law on Pandemic Response: A First Stocktaking in Light of the Coronavirus Crisis, op.cit, p.23

${ }^{107}$ Chenglin Liu, Regulating SARS in China: Law As an Antidote?, op.cit, p.86.

${ }_{108}$ Dr. Lucas Bergkamp, States liability for failure to Control the COVID-19 Epidemic - International and Netherlands, op.cit, p.354.

${ }^{109}$ See: Fact Check: China's Official Coronavirus Timeline Starts Out Weeks Too Late, Xinhua News, April 6, 2020. Available at: https://www.voanews.com/science-health/coronavirus-outbreak/fact-checkchinas-official-coronavirus-timeline-starts-out 
suspicious cases of SARS-like illness were detected in Wuhan, ${ }^{110}$ and of providing false information. ${ }^{111}$ Moreover, China delayed the accurate disclosure of two critical facts: the genome mapping and the human-to-human transmissibility. While reports indicate that China had mapped the genome of Covid-19 on 3 January 2020, it formally shared this information with the WHO on 9 January $2020 .^{112}$ Chinese authorities reiterated -officially- that they had found no evidence of the human-to-human transmissibility of the Covid-19 until 15 January $2020 ;{ }^{113}$ yet, the contrary was confirmed later. ${ }^{114}$ These two facts were critical for fighting the disease and if they had been known by people in advance, they could've avoided travelling to the infected city and, hence, prevented the transmission of the virus worldwide. ${ }^{115}$

As previously mentioned, the early notification about diseases along with accurate and clear information about any suspicious event that may pose a public health emergency, are of essence to enable the WHO to effectively assume its role in controlling

110 According to some reports, China waited 7 weeks before imposing a lockdown in Wuhan, by that time, it is estimated than already around 5 million people had left the infected city. See: 'Coronavirus: Trump aide claims China guilty of cover-up akin to Chernobyl', The Guardian, available at: https://www.theguardian.com/world/2020/may/24/coronavirus-donald-trumpadviser-china-who-chernobyl-golf

111 'Coronavirus: Trump aide claims China guilty of cover-up akin to Chernobyl', The Guardian, available at:https://www.theguardian.com/world/2020/may/24/coronavirus-donaldtrump-adviser-china-who-chernobyl-golf

112 See: DNA sleuths read the coronavirus genome, tracing its origins and looking for dangerous mutations, STAT News, 24 January 2020. Available at: https://www.statnews.com/2020/01/24/dna-sleuths-read-coronavirus-genometracing-origins-and-mutations/

${ }^{113}$ Dr. Lucas Bergkamp, States liability for failure to Control the COVID-19 Epidemic - International and Netherlands Law, op.cit, p.343.

114 How early signs of the coronavirus were spotted, spread and throttled in China, The Straits Times, 28 February 2020. Available at: https://www.straitstimes.com/asia/east-asia/how-early-signs-of-thecoronavirus-were-spotted-spread-and-throttled-in-china

${ }^{115}$ Paul J. Larkin, Jr., Suing China Over Covid-19, op.cit, pp.16-17. 
The WHO Response to the Pandemic Coronavirus (Covid-19) Outbreak: An Evaluation Under the Rule of International Law

Salwa Youssef Elekyabi

مجلة علمية محكمة

المجلة القانونية (مجلة متخصصة في الاراسات والبحوث القانونية)

pandemic outbreaks. Thus, based on the aforementioned facts, it appears that China has violated articles 6 and 7 of the IHR. According to Article 6, China should've notified the WHO about the Virus within 24 hours of assessing the event occurring in its territory. This didn't happen and, on the contrary, China ignored the early warning from a local doctor in Wuhan and underestimated the situation. Furthermore, it forcibly silenced early whistleblowers. ${ }^{116}$ So, it was late in assessing the event in its territory; in addition, when the situation was assessed, it was late in notifying the WHO.

According to Article 7, states should, upon notifying the WHO of a suspicious event, continue to provide the WHO with all updated and detailed information about the situation in their territories in a timely and accurately manner. This obligation too hasn't been fulfilled, as China provided inaccurate information about the transmissibility of the virus and delayed providing information about the genome mapping. ${ }^{117}$ When China notified the WHO about the virus, it indicated that it transmits from animals to humans and there is no evidence of human-to-human transmission; ${ }^{118}$ although, nearly one third of the reported cases, by

116 'Chinese officials note serious problems in coronavirus response: The World Health Organization keeps praising them', The Washington Post, 9 February 2020. Available at:

https://www.washingtonpost.com/world/asia_pacific/chinese-officials-noteserious-problems-in-coronavirus-response-the-world-health-organizationkeeps-praising-them/2020/02/08/b663dd7c-4834-11ea-91abce439aa5c7c1_story.html

${ }_{117}$ Morten Broberg, A Critical Appraisal of the World Health, Organization's International Health Regulations, op.cit, p. 207

118 See: China hid the severity of its coronavirus outbreak and muzzled whistleblowers — because it can, VOX, 10 February 2020. Available at: https://www.vox.com/future-perfect/2020/3/11/21175061/who-declarescoronavirus-covid-19-pandemic 
that time, had no history of visiting the infected seafood market. ${ }^{119}$ China, also, repeatedly refused offers from the WHO for epidemic investigation assistance until 28 of January $2020 .{ }^{120}$

In addition, China's clear violations of articles 6 and 7 of the IHR, have caused the epidemic Covid-19 to morph to a pandemic, which has been threatening the public health security in almost all states of the world. Simply, if clear, on-time and accurate information about the virus had been provided to the WHO, appropriate measures could've been taken to prevent travelling to the infected city, hence, preventing transmitting the virus to the whole world. According to a research study, if appropriate health measures had been taken in China in early December 2019, the number of worldwide Covid-19 cases could have been mitigated by up to $95 \%{ }^{121}$ Surprisingly, the WHO's director general, Tedros Adhanom Ghebreyesus, has praised the Chinese response to the crisis in many occasions. He's even applauded the transparency of the Chinese response and extoled the leadership of the Chinese President Xi Jinping in handling the Covid-19 crisis. ${ }^{122}$ This gave false impression to the whole world that the WHO and China are controlling the situation. ${ }^{123}$

${ }^{119}$ Devashsish Giri, Responsibility of China for the Spread of Covid-19: Can China Be Asked to Make Reparations?, JURIST - Student Commentary, April 10, 2020. Available at:

https://www.jurist.org/commentary/2020/04/devashsish-giri-china-covid19reparations/

$\frac{120}{12}$ 'Timeline of the Coronavirus': A frequently updated tracker of emerging developments from the beginning of the COVID-19 outbreak, Think Global Health, 27 July 2020. Available at:

https://www.thinkglobalhealth.org/article/updated-timeline-coronavirus

${ }_{121}$ Samir Saran, Covid19: Made in China pandemic, Observer Research Foundation, 20 March 2020. Available at: https://www.orfonline.org/expertspeak/covid19-made-in-china-pandemic-63531/

${ }^{122}$ See: WHO Director-General's statement on IHR Emergency Committee on Novel Coronavirus, 22 January 2020. Available at: https://www.who.int/dg/speeches/detail/who-director-general-s-statement-onihr-emergency-committee-on-novel-coronavirus

${ }^{123}$ In an interview with the Washington post, Professor Lawrence Gostin, of global health law at Georgetown University, has said that "we were deceived" 
The WHO Response to the Pandemic Coronavirus (Covid-19) Outbreak: An Evaluation Under the Rule of International Law

Salwa Youssef Elekyabi

مجلة علمية محكمة

المجلة القانونية (مجلة متخصصة في الاراسات والبحوث القانونية)

To sum up, it is clear that information sharing with respect to the ongoing crisis of Covid-19 by both China and the WHO have been defective. China has failed to fulfil its obligations as per the IHR and the WHO has failed to assume its responsibility to attract the global concern, in a timely and professional manner, to a serious health emergency. This has led to disastrous implications in all sectors and in every country affected by the virus. If these allegations are proven to be correct, China may be liable under international law based on wrongful acts; hence, it may be required to 'make full reparation for the injury caused by the internationally wrongful act.'

On the other hand, the case with the WHO is more complicated; the ongoing crisis has revealed significant shortcomings with relation to information sharing. The WHO was not able to receive adequate information from other sources to judge whether to declare a PHEIC. It depended mainly on information received from member states; so, if the states delayed or abstained from providing information, the decision to declare a PHEIC was delayed too. The WHO didn't have the mechanism to enforce its laws, particularly the IHR; however, the organization didn't remain silent with regard to the violations committed by China. At least, it could've 'named and shamed' the state's dilatory behavior, as had happened during the SARS crisis. On the contrary, the WHO praised the Chinese response to the crisis, though violations were clear, which raises concerns about the political involvement of the WHO in international matters.

and that "[himself] and other public health experts, based on what the World Health Organization and China were saying, reassured the public that this was not serious, that we could bring this under control". "Chinese officials note serious problems in coronavirus response. The World Health Organization keeps praising them', The Washington Post, 9 February 2020. Available at: https://www.washingtonpost.com/world/asia pacific/chinese-officials-noteserious-problems-in-coronavirus-response-the-world-health-organizationkeeps-praising-them/2020/02/08/b663dd7c-4834-11ea-91abce439aa5c7c1_story.html 


\section{Declaring Covid-19 a PHEIC}

By 3 January 2020, China had officially notified the WHO of a Novel Coronavirus outbreak in Wuhan city. However, it took the WHO almost a month to declare the event a Public Health Emergency of International Concern (PHEIC). ${ }^{124}$ The first step taken by the WHO to examine whether the event deserved to be declared as PHEIC was on 22 January 2020, when the DG decided to compose the 'Emergency Committee for Pneumonia due to the Novel Coronavirus 2019-nCoV'. ${ }^{125}$ The EC was tasked to assess the available information and advise whether the conditions to declare the Novel Coronavirus 2019-nCoV a PHEIC are met, as per the IHR.

In its first meeting on 22 January 2020, the EC's advice was that 'the event did not constitute a PHEIC'. During that meeting, and as provided by the WHO, there were divergent opinions between the expert members of the Committee; yet, the EC members agreed on the urgency of the situation and praised the 'strong containment measures' taken by China but didn't reach a decision. ${ }^{126}$ Given that the EC deliberations are not published, the only available information about the EC meetings are laconic statements. At that time, the total number of confirmed cases in China was 440 cases

124 The WHO declared Covid-19 outbreak a PHEIC on 30 January 2020. See: Coronavirus disease (COVID-19) Pandemic - Emergency Use Listing Procedure (EUL) open for in vitro diagnostics, the WHO. Available at: https://www.who.int/diagnostics laboratory/EUL/en/

${ }^{125}$ For the full list of the EC members, see: List of proposed members and advisers to International Health Regulations (IHR) Emergency Committee for Pneumonia due to the Novel Coronavirus 2019-nCoV, the WHO, 22 January 2020. Available at: https://www.who.int/ihr/procedures/novel-coronavirus2019/ec-22012020-members/en/

126 See: Statement on the meeting of the International Health Regulations (2005) Emergency Committee regarding the outbreak of novel coronavirus (2019-nCoV), the WHO, 23 January 2020. Available at: https://www.who.int/news-room/detail/23-01-2020-statement-on-the-meetingof-the-international-health-regulations-(2005)-emergency-committeeregarding-the-outbreak-of-novel-coronavirus-(2019-ncov) 
The WHO Response to the Pandemic Coronavirus (Covid-19) Outbreak: An Evaluation Under the Rule of International Law

Salwa Youssef Elekyabi

مجلة علمية محكمة

المجلة القانونية (مجلة متخصصة في الاراسات والبحوث القانونية)

and 9 deaths, with a few cases in a limited number of states around China. $^{127}$

On the following day, 23 January 2020, the number of confirmed cases in China increased to 557 cases and 17 deaths, with a new case in Singapore. ${ }^{128}$ China also provided the WHO with new information about the containment measures taken in Wuhan. That day, the EC reconvened based on the DG request, to examine the provided information by China and advise on the situation. During their meeting, the EC members' views were divergent; yet, the EC welcomed the efforts taken by China to contain the disease and reached a conclusion that 'it is still too early to declare a PHEIC, given its restrictive and binary nature'. ${ }^{129}$

This statement was criticized based on three grounds: firstly, the EC's advice not to declare a PHEIC was hinging on 'the restrictive and binary nature' of the disease, which seems to be an inaccurate interpretation of the required criteria for declaring an event a PHEIC. ${ }^{130}$ As per article 1 of the IHR, the PHEIC is defined as 'an extraordinary event, which is determined to constitute a public health risk to other States through the international spread of disease and to potentially require a coordinated international response'. Within this meaning, it has been argued that the 'international spread' does not require that the disease must have a

127 'Timeline of the Coronavirus': A frequently updated tracker of emerging developments from the beginning of the COVID-19 outbreak, Think Global Health, 27 July 2020. Available at:

https://www.thinkglobalhealth.org/article/updated-timeline-coronavirus

${ }^{128}$ Ibid.

129 See: Statement on the meeting of the International Health Regulations (2005) Emergency Committee regarding the outbreak of novel coronavirus (2019-nCoV), the WHO, 23 January 2020.

${ }_{130}$ Mark Eccleston-Turner, COVID-19 Symposium: The Declaration of a Public Health Emergency of International Concern in International Law. Available at: http://opiniojuris.org/2020/03/31/covid-19-symposium-thedeclaration-of-a-public-health-emergency-of-international-concern-ininternational-law/ 
local spread in another country, but rather should have a 'potential' or 'risk' of cross-transmission. Secondly, the EC statement referred to the earliness of declaring the situation a PHEIC. This seems to suggest an extra factor to declare a PHEIC, which is not prescribed in the IHR and seems to weigh more than the IHR criteria themselves. While, the EC statement should have rather focused on whether the criteria of declaring a PHEIC are met. Thirdly, it has been argued by several observers, that the WHO was showing deference to China, by praising its domestic measures to contain the disease, and ignoring the cross-border spread of the disease as a criterion for declaring a PHEIC. ${ }^{131}$

On 30 January 2020, the number of confirmed cases globally increased to 7818 cases, affecting 19 countries in all continents, except Antarctica. The EC members convened on that day and after praising the Chinese transparency and quick response to investigate the disease, they advised that 'the outbreak now meets the criteria for a [PHEIC]' and suggested temporary recommendations. ${ }^{132}$ Based on the EC advice, the DG declared the outbreak of Covid-19 a PHEIC.

By analyzing the aforementioned facts, it becomes clear that there was a deficiency in the decision-making mechanism of declaring an event a PHEIC. The EC is of a technical-scientific nature and should have provided a technical advice based on clear criteria as per the IHR; though, its interpretation to these criteria has been inconsistent throughout its work. For example, the 2014 wild polio was declared a PHEIC based on the 'risk' of international spread, ${ }^{133}$ while during the outbreak of Ebola virus disease (EVD)

${ }^{131}$ J. Benton Heath, Pandemic and other Health Emergencies, op.cit, p.14.

${ }^{132}$ Statement on the second meeting of the International Health Regulations (2005) Emergency Committee regarding the outbreak of novel coronavirus (2019-nCoV), 30 January 2020. Available at: https://www.who.int/newsroom/detail/30-01-2020-statement-on-the-second-meeting-of-the-internationalhealth-regulations-(2005)-emergency-committee-regarding-the-outbreak-ofnovel-coronavirus-(2019-ncov)

133 Mark Eccleston-Turner, COVID-19 Symposium: The Declaration of a Public Health Emergency of International Concern in International Law.

1732 
The WHO Response to the Pandemic Coronavirus (Covid-19) Outbreak: An Evaluation Under the Rule of International Law

Salwa Youssef Elekyabi

مجلة علمية محكمة

المجلة القانونية (مجلة متخصصة في الدراسات والبحوث القانونية)

in Democratic Republic of Congo, the EC convened two times in October 2018 and in April 2019 and, in both meetings, it advised that the event didn't deserve to be declared a PHEIC, although all criteria for such a declaration were met. ${ }^{134}$ The same happened with the ongoing outbreak of Covid-19, which demonstrates inconsistency in the work of the EC.

In addition, declaring an event a PHEIC has serious implications on states, adding to this the unnecessary global fear it surges. So, such a declaration should be utilized prudently by, simply, complying with the provisions of the IHR. On 25 April 2009, the DG declared the outbreak of the swine flu epidemic a PHEIC. This declaration was criticized as upsurging unnecessary fear and as having been taken too soon; consequently, many WHO member states did not comply with the related recommendations. ${ }^{135}$ This contrasts with declaring the EVD and the ongoing Covid-19 a PHEIC, which has been criticized as a dilatory response. According to the author, the EC is composed of experts in the field and the nature of its tasks and the outcome of its work are, supposedly, of a scientific-technical nature' so, interjecting new factors in evaluating the situation and unduly praising states can have undesirable effects and most importantly can alter its nature towards a political approach, which falls clearly beyond the WHO objectives and mandate.

\section{Health measures}

Upon declaring Covid-19 a PHEIC, the DG issued temporary recommendations, based on the EC's consultation, to all states, which aimed at preventing the spread of the disease and

Available at: http://opiniojuris.org/2020/03/31/covid-19-symposium-thedeclaration-of-a-public-health-emergency-of-international-concern-ininternational-law/

134 Mark Eccleston-Turner, Adam Kamradt-Scott, Transparency in IHR emergency committee decision making: the case for reform, op.cit, p.1.

${ }^{135}$ Morten Broberg, A Critical Appraisal of the World Health, Organization's International Health Regulations, op.cit, p. 204. 
minimizing interference with international traffic. ${ }^{136}$ The temporary recommendations have been mainly about restricting travel, widespread social distancing and quarantine. ${ }^{137}$ As per the IHR, states are required to adhere to the WHO recommendations, in addition, they may apply additional health measures. Generally, it has been noticed that through the ongoing Covid-19 crisis, states have tended to apply pervasive health measures, which goes beyond the intended meaning and purpose of the IHR.

Article 32 of the IHR obliged states, when applying any health measures, to respect people's dignity, human rights and fundamental freedoms and minimize any discomfort or distress associated with such measures. However, within the context of the ongoing Covid-19, reports indicate that Russia has closed its border with China and banned Chinese nationals from entering its territory, which constitutes a discrimination on grounds of nationality and has led to diplomatic tension between the two countries. ${ }^{138}$ Further, it has been attributed to the US President, Donald Trump, using the expression 'Chinese virus' and replacing the word 'Corona' in his written speeches with 'Chinese', 139 the

136 The IHR, Art 48/1/c.

${ }^{137}$ Key considerations for repatriation and quarantine of travellers in relation to the outbreak of novel coronavirus 2019-nCoV, WHO, 11 February 2020. Available at:

https://www.who.int/news-room/articles-detail/key-considerations-forrepatriation-and-quarantine-of-travellers-in-relation-to-the-outbreak-of-novelcoronavirus-2019-ncov/

${ }^{138}$ How Will the Coronavirus Outbreak Affect Russia-China Relations?, The Diplomate, 14 March 2020. Available at: https://thediplomat.com/2020/03/how-will-the-coronavirus-outbreak-affectrussia-china-relations/

${ }^{139}$ As per 'The Conversation report', Trumps has used the expression 'Chinese virus' over 20 times in March 2020. A photocopy of his speech's script shows the word 'corona' crossed out and replaced with 'Chinese'. See: Donald Trump's 'Chinese virus': the politics of naming, The Conversation, 22 April 2020. Available at: https://theconversation.com/donald-trumps-chinese-virusthe-politics-of-naming-136796 
The WHO Response to the Pandemic Coronavirus (Covid-19) Outbreak: An Evaluation Under the Rule of International Law

Salwa Youssef Elekyabi

مجلة علمية محكمة

المجلة القانونية (مجلة متخصصة في الاراسات والبحوث القانونية)

surging of racist acts against Asians in the US. ${ }^{140}$ This behavior doesn't only violate the IHR, but also the WHO guidelines, which suggests the need to avoid naming human diseases by places, cities, continents or animals. ${ }^{141}$

Article 26 prevents the application of any health measures to a civilian lorry, train or coach that are not coming from an area affected with a disease, but rather passing through an affected territory without embarking, disembarking, loading or discharging. Since the outbreak of Covid-19 in Europe, Austria has inspected trains travelling from Italy to southern Germany; moreover, it has banned trains from traveling to and from Italy via a key international route. ${ }^{142}$ This practice clearly violates the IHR.

Given that article 40 permits states to charge travelers for medical examinations, some states have taken actions in accordance with this article but this has proven to be costly for travelers. Germany was one of the first countries to charge travelers between $€ 59$ and $€ 139$ for the PCR test at Frankfurt Airport. ${ }^{143}$ Other states have required the PCR test only from travelers who arrive from 'highrisk' countries. For example, France has issued the red-list countries, which include 16 high-risk countries and has required

140 As Coronavirus Spreads, So Does Xenophobia and Anti-Asian Racism, Time, 6 March 2020. Available at: https://time.com/5797836/coronavirusracism-stereotypes-attacks/

141 See: WHO best practices for naming of new human infectious diseases, 2015.

Available

at:https://apps.who.int/iris/bitstream/handle/10665/163636/WHO HSE FOS 1 5.1 eng.pdf?sequence $=1$

142 Coronavirus: Austria briefly halts trains from Italy over COVID-19

concerns, DW News, 23 February 2020. Available at: https:/www.dw.com/en/coronavirus-austria-briefly-halts-trains-from-italyover-covid-19-concerns/a-52493063

${ }^{143}$ Covid-19 airport testing in the UK, Europe and the rest of the world, NS Medical Devices, 31 July 2020. Available at: https://www.nsmedicaldevices.com/analysis/covid-19-testing-airports/ 
compulsory PCR testing from travelers arriving from any of these countries. $^{144}$

During the climax of the Covid-19 outbreak, closures of schools and universities, bans on large gatherings and domestic traveling, in addition to overall mass quarantine, which is also known as 'lockdowns', were common in almost every country. ${ }^{145}$ These measures were necessary for containing the disease and apparently fall within the realm of the temporary measures; however, in some countries, these measures were excessively applied. In Azerbaijan, the national government imposed a very strict lockdown, which took place from 6 to 8 June 2020. During that period, the police used lethal force to impose curfew, people were not allowed to leave their homes except for medical emergencies, and all markets and pharmacies were closed. ${ }^{146}$

According to Article 43, states are required, when applying any additional health measures to ensure that these are not more restrictive or invasive 'than reasonably available alternatives'. ${ }^{147}$ States should, when determining the reasonability of the additional health measures, base their determination on scientific principles; available scientific evidence and information; and any guidance or advice from the WHO. ${ }^{148}$ Further, states should provide the WHO with scientific justification for applying any additional health measures. The ongoing Covid-19 crisis has revealed that some states are imposing excessive health measures that were either prohibited by the IHR or ill-justified. ${ }^{149}$ However, as with

${ }^{144}$ Ibid.

${ }^{145}$ Lawrence O. Gostin, Eric A. Friedman, and Sarah A. Wetter, Responding to Covid-19: How to Navigate a Public Health Emergency Legally and Ethically, op.cit, p.4.

${ }^{146}$ Excessive measures adopted in the context of the COVID-19 pandemic in Azerbaijan, Civil Society Forum, 16 June 2020. Available at: https://eapcsf.eu/project/excessive-measures-during-covid-19-pandemicazerbaijan/?lang=en

147 The IHR, Art. 43 (1).

148 The IHR, Art. 43 (2).

149 Chiara Giorgetti, International Health Emergencies in Failed and Failing States, op.cit, p.15. 
The WHO Response to the Pandemic Coronavirus (Covid-19) Outbreak: An Evaluation Under the Rule of International Law

Salwa Youssef Elekyabi

مجلة علمية محكمة

المجلة القانونية (مجلة متخصصة في الاراسات والبحوث القانونية)

information sharing, the IHR lacks enforcement mechanisms to impose compliance; accordingly, the WHO relies on state reports and justifications provided by states. ${ }^{150}$ According to the WHO, as of 9 March 2020, a total of 45 states parties had informed the WHO of implemented additional health measures in their territories and provided the public health rationale for these measures. ${ }^{151}$ By that time, it was estimated that the total number of affected states was around 70, which shows that at least more than twenty countries had implemented measures without providing justifications to the WHO. This situation is quite similar to the 2014 Ebola outbreak; as, more than forty states had implemented additional health measures without providing the WHO with information or rationale for implementing these measures, despite that some measures were seen to be excessive and unjustified. ${ }^{152}$

In contrast, China was criticized for not implementing early restrictive measures to contain the disease. It has been argued that China delayed imposing quarantine in Wuhan for more than a month. The Chinese government allowed the celebration of the New Year eve hosted by Wuhan's leaders with the participation of nearly 40,000 residents, despite the risk of mass infection. China also allowed international travel with screening to around five million people from Wuhan to many places around the world. ${ }^{153}$

${ }^{150}$ J. Benton Heath, Pandemic and other Health Emergencies, op.cit, p.11.

${ }^{151}$ Coronavirus disease 2019 (COVID-19) Situation Report, WHO, 10 March 2020. Available at: https://www.who.int/docs/defaultsource/coronaviruse/situation-reports/20200310-sitrep-50-covid19.pdf?sfvrsn $=55 \mathrm{e} 904 \mathrm{fb} 2$

${ }^{152}$ During that time, Canada and Australia imposed a near blanket travel restriction on travelers from West Africa in violation to the WHO's recommendation. When the WHO requested public health rationales from these two countries as provided in the IHR, they both didn't comply.

${ }^{153}$ Paul J. Larkin, Jr., Suing China Over Covid-19, op.cit, pp.16-17 
المجلة القانونية (مجلة متخصصة في الدراسات والبحوث القانونية)

(ISSN: 2537 - 0758)

\section{Bioweapon Conspiracy Theory}

The lack of clarity and contradiction of information about the Virus has led to allegations that Covid-19 might be a bioweapon masterminded by states. ${ }^{154}$ Although doubtful, conspiracy theories have appeared during previous pandemics, ${ }^{155}$ for example, it was alleged that Jews are the source of the bubonic plague during the $14^{\text {th }}$ century. Similarly, it was claimed that Bayer, the German pharmaceutical company, has a hand in spreading the Spanish Flu through selling pharmaceutical drugs tainted with the Virus. ${ }^{156}$ The same happened in the age of internet and social media. Russia has frequently claimed that the West is responsible for creating the Virus, thus, feeding the idea of conspiracy theory. ${ }^{157}$ The White House has frequently referred to China as covering-up the truth that will "go down in history along with Chernobyl", implying the likelihood of the Covid-19 being a bioweapon manufactured by China. ${ }^{158}$ Also, it was claimed that China may developed Covid-19

154 Peter Okediya, China Coronavirus Bioweapon Conspiracy Theory: The Application of International Humanitarian Law by States (May 18, 2020). Available at: https://ssrn.com/abstract $=3614166$

${ }^{155}$ In a recent survey conducted by researchers in the U.S between March and July 2020, it was found that $37 \%$ believed that the Chinese government created the coronavirus as a bioweapon, $32 \%$ believed that the U.S. Centers for Disease Control and Prevention, or CDC, are exaggerating the danger posed by the virus in order to damage Donald Trump's presidency, and $17 \%$ believed that the pharma industry created the virus to increase sales of drugs and vaccines. See: Belief in pandemic conspiracy theories is an obstacle to minimize the spread of COVID-19, News Medical Life science, 22 September 2020. Available at: https://www.news-medical.net/news/20200922/Belief-in-pandemic-conspiracytheories-is-an-obstacle-to-minimizing-the-spread-of-COVID-19.aspx

${ }^{156}$ Brie DeBusk Sherwin, Anatomy of a Conspiracy Theory: Law, Science, and Politics in the COVID-19 Era, July 1, 2020. Texas A\&M Law Review (Spring 2021 Forthcoming), Available at: https://ssrn.com/abstract $=3681728$

${ }^{157}$ Sukhankin, Sergey, COVID-19 As a Tool of Information Confrontation: Russia's Approach, April 1, 2020. The School of Public Policy Publications, Volume 13:3, April 2020. Available at: https://ssrn.com/abstract $=3566689$

158 Coronavirus: Trump aide claims China guilty of cover-up akin to Chernobyl, The Guardian, available at: https://www.theguardian.com/world/2020/may/24/coronavirus-donald-trumpadviser-china-who-chernobyl-golf 
The WHO Response to the Pandemic Coronavirus (Covid-19) Outbreak: An Evaluation Under the Rule of International Law

Salwa Youssef Elekyabi

مجلة علمية محكمة

المجلة القانونية (مجلة متخصصة في الاراسات والبحوث القانونية)

as a bioweapon, while having the anti-viral medicine at the same time. Then, once the virus attains certain threshold, China will reveal finding a cure and sell it to all countries. ${ }^{159}$ Moreover, the accusations against China went far by claiming that the Virus was introduced in Wuhan lab, that is linked to Beijing's covert biological weapons program, ${ }^{160}$ then it was transmitted to Wuhan wild-life market. ${ }^{161}$

These allegations might be supported by the assumption that China is aiming to gain an upper hand in the global economy. China has also managed to suppress the spread of the disease in its territory efficiently better than any other country. The death rate in some countries were much higher than inside China. All these facts are feeding the conspiracy theory that Covid-19 might be a bioweapon made by China, however, never been supported with solid grounds or evidence yet. In one hand, the Wuhan lab is widely recognized as a research center which had previously developed various treatments for viruses such as SARS. ${ }^{162}$ In the other hand, as been argued by one author, Covid-19 is not a "desired" bioweapon, although it lines up with some "desirable" properties of the bioweapons, ${ }^{163}$ such as: easy access, easy manufacture, stability in

${ }^{159}$ Peter Okediya, China Coronavirus Bioweapon Conspiracy Theory: The Application of International Humanitarian Law by States, op.cit., p.1.

${ }^{160}$ This is according to Dany Shoham, a former Israeli military intelligence officer. See: Coronavirus may have origins in China's biological warfare lab in Wuhan, The News Scroll, 26 January 2020. Available at: https://www.outlookindia.com/newsscroll/coronavirus-may-have-origins-inchinas-biological-warfarelab-in-wuhan/1717828

$\frac{161}{16}$ Peter Okediya, China Coronavirus Bioweapon Conspiracy Theory: The Application of International Humanitarian Law by States, op.cit., p.1.

${ }^{162}$ Ibid.

${ }^{163}$ Dr. Mark Kortepeter, A Defense Expert Explores Whether the Covid-19 Coronavirus Makes A Good Bioweapon, Forbes, 21 August 2020. Available at: https://www.forbes.com/sites/coronavirusfrontlines/2020/08/21/a-defenseexpert-explores-whether-the-covid-19-coronavirus-makes-a-goodbioweapon/?sh $=557 \mathrm{c} 45007 \mathrm{ece}$ 
the atmosphere, widespread, large-scale infection, contagiousness, protectiveness of the users, and the threat of use can cause panic. ${ }^{164}$

In all cases, whether or not these allegations are valid, the role of investigating and dealing with any alleged case of developing or utilizing bioweapons is vested in the UN Secretary- General. Further, the legal framework on the prohibition of developing and using biological weapons falls within the scope of the International Humanitarian Law (IHL). ${ }^{165}$ Though, the WHO, as an expert organization, was involved in fighting the development and usage of the biological weapons. On 29 January 1969, the WHO was invited to participate in the UN Group of Consultants Experts on Chemical and Bacteriological (Biological) Weapons to prepare a report on the subject. Back then, the WHO was regarded as useful for the UN report. Further, the WHO expressed its concern with matters related to the development and use of chemical and bacteriological weapons. For example, in 1967, the WHO adopted a resolution welcoming Resolution 2162 (XXI) of the UN General

${ }^{164}$ According to centers for disease control and prevention (CDC) in the U.S, Category A of the Bioterrorism Agent/Diseases is defined as “... organisms that pose a risk to national security because they can be easily disseminated or transmitted from person to person; result in high mortality rates and have the potential for major public health impact; might cause public panic and social disruption; and require special action for public health preparedness". Bioterrorism Agents/Diseases, CDC. Available at: https://emergency.cdc.gov/agent/agentlist-category.asp\#catdef

165 Within the scope of IHL, the conventions on the prohibition of the development and the utilization of chemical and biological weapons include: the 1907 Hague Convention on Land Warfare (article 23), the 1925 Geneva Protocol, which clearly prohibits the use of chemical and biological weapons in war, the 1975 Convention on the Prohibition of the Development, Production, Stockpiling of Bacteriological (Biological) and Toxin Weapons and on their Destruction (The Biological Weapon Convention "BWC"), and the 1997 Convention on the Prohibition of the Development, Production, Stockpiling and Use of Chemical Weapons and on their Destruction (the Chemical Weapons Convention "CWC"). See: United Nations Office for Disarmament Affairs at: https://www.un.org/disarmament/ 
The WHO Response to the Pandemic Coronavirus (Covid-19) Outbreak: An Evaluation Under the Rule of International Law

Salwa Youssef Elekyabi

مجلة علمية محكمة

$$
\text { المجلة القانونية (مجلة متخصصة في الاراسات والبحوث القانونية) }
$$

Assembly and induced all member states of the WHO to comply with the resolution. ${ }^{166}$

In 1980, the UN Secretary-General has developed a mechanism to carry out prompt investigations in response to allegations of using biological and toxin weapons. This mechanism is triggered by a request from any member state. Based on this request, the Secretary-General is authorized to launch an investigation and to report about the allegation. ${ }^{167}$ In order to enhance this mechanism and strengthen the investigation, UN has signed, on 11 January 2011, a Memorandum of Understanding with the WHO. The Memorandum included provisions on sharing information, assigning focal points, conducting joint activities, and providing technical support in assessing the alleged case. ${ }^{168}$

Accordingly, to validate the allegation of Covid-19 being a bioweapon deliberately unleashed by China, a request for investigation should be submitted to the UN Secretary-General by a state member. Until that time, the available valid evidences are those of the WHO, including the "Report of the WHO-China Joint Mission on Coronavirus Disease 2019 (Covid-19)", which clearly

166 For more see: Ensuring Effective Interagency Interoperability and Coordinated Communication in Case of Chemical and/or Biological Attacks, UN 2017. Available at:

https://www.un.org/sites/www.un.org.counterterrorism/files/uncct ctitf wmd wg project publication final.pdf

167 Secretary-General's Mechanism for Investigation of Alleged Use of Chemical and Biological Weapons, UNODA. Available at: https://www.un.org/disarmament/wmd/secretary-general-mechanism/

168 Memorandum of Understanding between the World Health Organization and the United Nations Concerning WHO's support to the Secretary-General's Mechanism for Investigation of the Alleged use of Chemical, Biological or Toxin Weapons. Available at: https://unoda-web.s3-accelerate.amazonaws.com/wpcontent/uploads/assets/WMD/SecretaryGeneral_Mechanism/UN_WHO_MOU_2011.pdf 
debunks the claim that the Covid-19 is a man-made weapon. ${ }^{169}$ Though, according to one author, this report might be biased "due to the fact that $64 \%$ (16 out of 25) of the Joint Mission members that prepared the report were Chinese nationals". ${ }^{170}$

\section{IV.Conclusion:}

This article showed in part I that the WHO lies in the heart of the 'global health governance', given that it is the main actor on the international health sphere, that is entrusted with extensive powers and authority to act in times of global health emergencies. The scientific-technical approach of the organization is intended to distinguish the WHO as an expert organization, which introduces to its member states purely scientific-technical advice. However, the ongoing Covid-19 crisis has revealed the opposite, or it can be safely said that while past health emergencies have revealed certain weakness in the WHO, Covid-19 has demonstrated the organization's abject failure. In part II of this article, the author pointed to the main normative deficiencies in the legal framework of the WHO, which had previously been discussed by many scholars when commenting on past health emergencies. As was discussed in part II, there is a need for transparent mechanisms for conducting all businesses within the WHO, especially decisionmaking, an enforcement mechanism to impose compliance on states, and a rigorous system to assist states to build their capacity.

As was explained in part III of this article, the WHO response to the ongoing Covid-19 crisis hasn't reflected the WHO as 'the directing and coordinating authority on international health work'. ${ }^{171}$ In the author's view, the role of the WHO during the ongoing crisis can be best described as marginal and its response as relented. The WHO has not succeeded in assuming its ambitious

\footnotetext{
${ }^{169}$ Report of the WHO-China Joint Mission on Coronavirus Disease 2019 (Covid-19). Available at: https://www.who.int/docs/defaultsource/coronaviruse/who-china-joint-mission-on-covid-19-final-report.pdf ${ }^{170}$ Peter Okediya, China Coronavirus Bioweapon Conspiracy Theory: The Application of International Humanitarian Law by States, op.cit., p.5.

${ }^{171}$ The WHO Constitution, Art. 2.
} 
The WHO Response to the Pandemic Coronavirus (Covid-19) Outbreak: An Evaluation Under the Rule of International Law

Salwa Youssef Elekyabi

مجلة علمية محكمة

المجلة القانونية (مجلة متخصصة في الاراسات والبحوث القانونية)

role to 'stimulate and advance work to eradicate epidemic, endemic and other diseases 'as described in its constitution, or "prevent, protect against, control and provide a public health response to the international spread of disease' as provided in the IHR. China concealed information about the early days of the outbreak and then provided inaccurate information; other states didn't notify the WHO about the early cases in their territories; additionally, practice has shown non-compliance with the WHO recommendations and different violations from states to the IHR; while, the WHO has remained silent throughout all this. Considering the above, it is hard to admit that the WHO is still assuming its position in 'the heart of the global health governance'.

Accordingly, a comprehensive reform of the WHO is necessary, if the global leadership role of the WHO is to be retained. Some argue $^{172}$ - including this author- that the WHO has not been legally equipped with the necessary tools to achieve its ambitious broad mission: 'the attainment by all peoples of the highest possible level of health.' ${ }^{173}$ Thus, the reform should target the institutional structure of the WHO, in order to commensurate the role of the organization as the main actor for the global health governance, and to combine between the coordination task on the international level and the complex political cooperation. This article has suggested some solutions in this direction and has addressed questions in this regard; however, it is unclear whether a political will for such reform exists.

${ }^{172}$ J. Benton Heath, Pandemic and other Health Emergencies, op.cit, p.21. Eyal Benvenisti, The WHO - Destined to Fail?: Political Cooperation and the COVID-19 Pandemic, op.cit, p.1.

${ }^{173}$ The WHO Constitution, Art.1. 


\section{List of References:}

\section{(1) Articles:}

- A. Louis Evans, Confronting Global Pandemics: Responding to A State's Refusal of International Assistance in a Pandemic, 34 Conn. J. Int'l L. 1, Fall 2018.

- Allyn Lise Taylor, Making the World Health Organization Work: A Legal Framework for Universal Access to the Conditions for Health, 18 Am. J. L. and Med. 301.

- Allyn Taylor \& Emily Bruemmer, Institutional Transparency and Global Health Lawmaking: Case Study of the International Health Regulations, In Andrea Bianchi and Anne Peters (eds.): Transparency in International Law, Cambridge University Press, (2013).

- Armin Von Bogdandy and Pedro A. Villarreal, International Law on Pandemic Response: A First Stocktaking in Light of the Coronavirus Crisis (March 26, 2020), Max Planck Institute for Comparative Public Law \& International Law (MPIL) Research Paper No. 2020-07.

- Brie DeBusk Sherwin, Anatomy of a Conspiracy Theory: Law, Science, and Politics in the COVID-19 Era, July 1, 2020. Texas A\&M Law Review (Spring 2021 Forthcoming), Available at: https://ssrn.com/abstract $=3681728$

- Chiara Giorgetti, International Health Emergencies in Failed and Failing States, 44 Geo. J. Int'1 L. 1347.

- Chenglin Liu, Regulating SARS in China: Law as an Antidote?, Washington University Global Studies Law Review Vol. 4, 2005.

- David P. Fidler, The Future of the World Health Organization: What Role for International Law?, 31 Vand. J. Transnat'l L.

- David P. Fidler, Governance and The Globalization of Disease (2004).

- Devashsish Giri, Responsibility of China for the Spread of Covid19: Can China Be Asked to Make Reparations?, JURIST - Student Commentary, April 10, 2020.

- Eccleston-Turner M, Kamradt-Scott A Transparency in IHR emergency committee decision making: the case for reform BMJ Global Health $2019 . \quad$ Available at: https://gh.bmj.com/content/4/2/e001618

- Eric E. Johnson \& Theodore C. Bailey, Urgent Legal Lessons from a Very Fast Problem: Covid-19, 73 STAN. L. REV, 2020. 
The WHO Response to the Pandemic Coronavirus (Covid-19) Outbreak: An Evaluation Under the Rule of International Law

Salwa Youssef Elekyabi

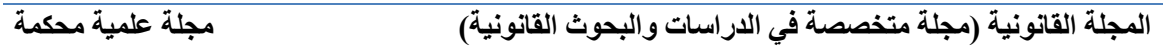

- Eyal Benvenisti, The WHO - Destined to Fail?: Political Cooperation and the COVID-19 Pandemic (June 30, 2020), University of Cambridge, Faculty of Law Research Paper No. 24/2020.

- J. Benton Heath, Pandemic and other Health Emergencies, Oxford Handbook of International Law and Global Security (forthcoming), July 27, 2020, Temple University Legal Studies Research Paper No. 2020-12.

- J. Benton Heath, Global Emergency Power in the Age of Ebola, 57 Harv. Int'l L.J. 1.

- Jose E. Alvarez, The WHO in the Age of the Coronavirus (July 13, 2020), NYU School of Law, Public Law Research Paper No. 20-30.

- Lawrence O. Gostin, Eric A. Friedman, and Sarah A. Wetter, Responding to Covid-19: How to Navigate a Public Health Emergency Legally and Ethically, Hastings Center Report 50, no. 2 (2020).

- Dr. Lucas Bergkamp, States liability for failure to Control the COVID-19 Epidemic - International and Netherlands Law, Accepted Manuscript for European Journal of Risk Regulation as part of the Cambridge Coronavirus Collection, published online on 2 April 2020. Available at: https://www.cambridge.org/core/services/aop-cambridgecore/content/view/5250CAA5A15C0D9FB9EA490404BA1AE4/S1 867299X20000215a.pdf/state liability for failure to control the covid19 epidemic international and dutch law.pdf

- Mark Eccleston-Turner, Adam Kamradt-Scott, Transparency in IHR emergency committee decision making: the case for reform, BMJ Global Health, August 2020.

- Mark Eccleston-Turner, COVID-19 Symposium: The Declaration of a Public Health Emergency of International Concern in International Law. Available at: http://opiniojuris.org/2020/03/31/covid-19symposium-the-declaration-of-a-public-health-emergency-ofinternational-concern-in-international-law/

- Mark J. Volansky, Achieving Global Health: A Review of The World Health Organization's Response, 10 Tulsa J. Comp. \& Int'l L.

- Morten Broberg, A Critical Appraisal of the World Health, Organization's International Health Regulations, (2005) in Times of 


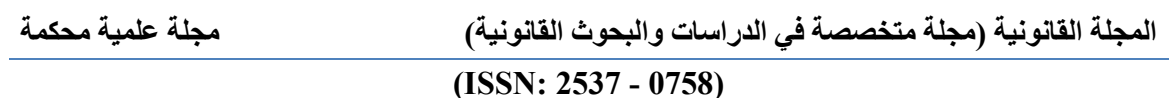

Pandemic: It is Time for Revision, European Journal of Risk Regulation, 2020, vol.11.2.

- Paul J. Larkin, Jr., Suing China Over Covid-19, 100 B.U. L. Rev. Online 91.

- Peter Okediya, China Coronavirus Bioweapon Conspiracy Theory: The Application of International Humanitarian Law by States (May 18, 2020). Available at: https://ssrn.com/abstract $=3614166$

- Samir Saran, Covid19: Made in China pandemic, Observer Research Foundation, 20 March 2020. Available at: https://www.orfonline.org/expert-speak/covid19-made-in-chinapandemic-63531/

- Sukhankin, Sergey, COVID-19 as a Tool of Information Confrontation: Russia's Approach, April 1, 2020, The School of Public Policy Publications, Volume 13:3, April 2020. Available at: https://ssrn.com/abstract $=3566689$

- Tsung-Ling Lee, Making International Health Regulations Work: Lessons from the 2014 Ebola Outbreak, 49 Vand. J. Transnat'l L.

(2) Reports:

- WHO, Report of the Review Committee on the Functioning of the International Health Regulations (2005) in Relation to Pandemic (H1N1) 2009, U.N. Doc. P 18 A64/10 (May 5, 2011), http://apps.who.int/gb/ebwha/pdf files/WHA64/A64 10-en.pdf.

- Bioterrorism Agents/Diseases, CDC. Available at: https://emergency.cdc.gov/agent/agentlist-category.asp\#catdef

- Report of the WHO-China Joint Mission on Coronavirus Disease 2019 (Covid-19). Available at: https://www.who.int/docs/defaultsource/coronaviruse/who-china-joint-mission-on-covid-19-finalreport.pdf

(3) Treaties:

- The UN Charter

- The WHO constitution

- The Framework Convention on Tobacco Control, adopted in May 2003, and entered into force in 2005. Available at http://www.who.int/tobacco/framework/en/.

- The International Health Regulations. available at: https://apps.who.int/iris/bitstream/handle/10665/246107/978924158 0496-eng.pdf? sequence $=1$ 